\title{
Acute Knockdown of Kv4.1 Regulates Repetitive Firing Rates and Clock Gene Expression in the Suprachiasmatic Nucleus and Daily Rhythms in Locomotor Behavior
}

\author{
Tracey O. Hermanstyne,, ${ }^{1, *}$ DDaniel Granados-Fuentes, ${ }^{2, *}$ Rebecca L. Mellor, ${ }^{1}{ }^{\circ}$ Erik D. Herzog, ${ }^{2}$ and
} (1) Jeanne M. Nerbonne ${ }^{1, *}$

DOI:http://dx.doi.org/10.1523/ENEURO.0377-16.2017

${ }^{1}$ Departments of Developmental Biology and Internal Medicine Washington University School of Medicine, Washington University, St. Louis, MO 63130, and ${ }^{2}$ Department of Biology, Washington University, St. Louis, MO 63130

\begin{abstract}
Rapidly activating and inactivating A-type $\mathrm{K}^{+}$currents $\left(\mathrm{I}_{A}\right)$ encoded by $\mathrm{Kv} 4.2$ and $\mathrm{Kv} 4.3$ pore-forming $(\alpha)$ subunits of the Kv4 subfamily are key regulators of neuronal excitability. Previous studies have suggested a role for Kv4.1 $\alpha$-subunits in regulating the firing properties of mouse suprachiasmatic nucleus (SCN) neurons. To test this, we utilized an RNA-interference strategy to knockdown Kv4.1, acutely and selectively, in the SCN. Current-clamp recordings revealed that the in vivo knockdown of Kv4.1 significantly $(p<0.0001)$ increased mean \pm SEM repetitive firing rates in SCN neurons during the day $(6.4 \pm 0.5 \mathrm{~Hz})$ and at night $(4.3 \pm 0.6 \mathrm{~Hz})$, compared with nontargeted shRNAexpressing SCN neurons (day: $3.1 \pm 0.5 \mathrm{~Hz}$; night: $1.6 \pm 0.3 \mathrm{~Hz}) . \mathrm{I}_{\mathrm{A}}$ was also significantly $(p<0.05)$ reduced in Kv4.1-targeted shRNA-expressing SCN neurons (day: $80.3 \pm 11.8 \mathrm{pA} / \mathrm{pF}$; night: $55.3 \pm 7.7 \mathrm{pA} / \mathrm{pF}$ ), compared with nontargeted shRNA-expressing (day: $121.7 \pm 10.2 \mathrm{pA} / \mathrm{pF}$; night: $120.6 \pm 16.5 \mathrm{pA} / \mathrm{pF}$ ) SCN neurons. The magnitude of the effect of $\mathrm{Kv} 4.1$-targeted shRNA expression on firing rates and $\mathrm{I}_{\mathrm{A}}$ was larger at night. In addition, Kv4.1-targeted shRNA expression significantly $(p<0.001)$ increased mean \pm SEM nighttime input resistance $\left(R_{\text {in }} ; 2256 \pm 166 \mathrm{M} \Omega\right)$, compared to nontargeted shRNA-expressing SCN neurons $(1143 \pm 93 \mathrm{M} \Omega$ ). Additional experiments revealed that acute knockdown of Kv4.1 significantly $(p<0.01)$ shortened, by $\sim 0.5 \mathrm{~h}$, the circadian period of spontaneous electrical activity, clock gene expression and locomotor activity demonstrating a physiological role for Kv4.1-encoded $\mathrm{I}_{\mathrm{A}}$ channels in regulating circadian rhythms in neuronal excitability and behavior.
\end{abstract}

Key words: A-type current; action potential waveforms; Kv channels; Period2; repetitive firing properties; SCN

\section{Significance Statement}

Neurons in the suprachiasmatic nucleus (SCN) use a transcription-translation feedback loop to generate daily changes in input resistances $\left(R_{\text {in }}\right)$ and firing rates that drive rhythms in physiology and behavior, although the molecular determinants underlying the daily changes in membrane properties have not been identified. We show here that Kv4.1 contributes to the generation of $\mathrm{I}_{\mathrm{A}}$ and the regulation of the circadian period of electrical activity and clock gene expression in SCN neurons as well as locomotor behavior. These observations provide the first demonstration of a physiologic role for $\mathrm{Kv} 4.1$-encoded $\mathrm{I}_{\mathrm{A}}$ channels in the mammalian brain. In addition, we show that the effects of Kv4.1 knockdown on $\mathrm{I}_{A}, \mathrm{R}_{\text {in }}$, and repetitive firing rates are greater at night than during the day.

\section{Introduction}

Voltage-gated $\mathrm{K}^{+}\left(\mathrm{K}_{\mathrm{v}}\right)$ channels are key regulators of neuronal excitability, functioning to control resting membrane potentials $\left(\mathrm{V}_{\mathrm{r}}\right)$, action potential waveforms, repeti-

Received December 19, 2016; accepted May 7, 2017; First published May 12, 2017.

The authors declare no competing financial interests. tive firing rates, as well as to modulate neurotransmitter release and synaptic plasticity (Rudy, 1988; Pongs, 1999). Multiple types of neuronal $K_{v}$ channels with distinct timeand voltage-dependent properties and functional roles 
have been identified (Pongs, 1999; Gutman et al., 2005). Rapidly activating and inactivating A-type $\mathrm{K}_{\mathrm{v}}$ currents $\left(\mathrm{I}_{\mathrm{A}}\right)$, for example, are widely expressed in the mammalian central nervous system (Rogawski, 1985; Rudy, 1988; Hoffman et al., 1997; Jerng et al., 2004), and several studies have linked Kv4.2 and Kv4.3, pore-forming $(\alpha)$ subunits of the Kv4 subfamily (Baldwin et al., 1991; Serodio et al., 1996) to the generation of $I_{A}$. Electrophysiological experiments on hippocampal pyramidal CA1 neurons, for example, revealed a prominent role for Kv4.2 in shaping dendritic action potential waveforms (Kim et al., 2005). In cortical pyramidal neurons, however, both $\mathrm{Kv} 4.2$ and $\mathrm{Kv} 4.3$ contribute to the generation of $\mathrm{I}_{\mathrm{A}}$ and the regulation of excitability (Carrasquillo et al., 2012). Although in situ hybridization studies have revealed that the third member of the Kv4 subfamily, Kv4.1, is also expressed in the rodent brain, the level of expression of Kv4.1 is low, in most brain regions, particularly when compared with Kv4.2 or Kv4.3 (Serodio and Rudy, 1998).

In the suprachiasmatic nucleus (SCN), the hypothalamic structure that controls circadian rhythms in mammalian physiology and behavior (Kalsbeek and Buijs, 2002; Colwell, 2011), $I_{A}$ has been shown to be expressed and to modulate neuronal firing properties (Bouskila and Dudek, 1995; Alvado and Allen, 2008; Itri et al., 2010; Granados-Fuentes et al., 2012; Granados-Fuentes et al., 2015). Voltage-clamp recordings from SCN neurons in slices prepared from mice harboring targeted disruptions in Kcnd2 (Kv4.2) or Kcnd3 (Kv4.3) revealed a role for $\mathrm{Kv} 4.2$, but not Kv4.3, in the generation of $\mathrm{I}_{\mathrm{A}}$ (GranadosFuentes et al., 2012). It has, however, also been reported that Kv4.1 is expressed in the SCN, suggesting a functional role for $\mathrm{Kv} 4.1$ in the generation of $\mathrm{I}_{\mathrm{A}}$ and in the regulation of SCN timing (Itri et al., 2010). To test this hypothesis directly, we developed an RNA-interference based strategy to examine the effects of acute, in vivo knockdown of Kv4.1 in the SCN. Whole-cell patch-clamp recordings from SCN cells expressing the Kv4.1-targeted shRNA revealed that knockdown of Kv4.1 expression increased repetitive firing rates and reduced macroscopic $\mathrm{I}_{\mathrm{A}}$. Additional experiments revealed that acute knockdown of Kv4.1 shortened circadian periodicity in electrical activity, clock gene expression and locomotor activity.

This work was supported by the National Institute of General Medical Sciences Grant R01 GM104991 (to E.D.H. and J.M.N.) and by a UNCF/Merck Postdoctoral Fellowship to T.O.H

*T.O.H. and D.G.-F. contributed equally.

Acknowledgements: We thank members of the Nerbonne and Herzog laboratories for helpful discussions and Richard Wilson for technical assistance.

Correspondence should be addressed to Jeanne M. Nerbonne, Department of Medicine, Cardiovascular Division, Washington University School of Medicine, Box 8086, 660 South Euclid Avenue, St. Louis, MO 63110, E-mail: jnerbonne@wustl.edu.

DOI:http://dx.doi.org/10.1523/ENEURO.0377-16.2017

Copyright (C) 2017 Hermanstyne et al.

This is an open-access article distributed under the terms of the Creative Commons Attribution 4.0 International license, which permits unrestricted use, distribution and reproduction in any medium provided that the original work is properly attributed.

\section{Methods and Materials}

All reagents were obtained from Sigma-Aldrich, unless otherwise noted.

\section{Animals}

All procedures involving animals were approved by the Animal Care and Use Committee and were conducted in accordance with the United States National Institutes of Health Guidelines for the Care and Use of Laboratory Animals. Mice were maintained on a C57BI/6JN background (WT) in the Danforth and Medical School animal facilities. The Per2 ${ }^{\text {Luc }}$ mouse line, generated by replacing the endogenous mouse Per2 locus with a PERIOD2:: LUCIFERASE (PER2::LUC) reporter construct (Yoo et al., 2004), was obtained from Dr. J. Takahashi (University of Texas Southwestern, Dallas, TX).

\section{shRNA screening and validation of Kv4.1-targeted knockdown specificity}

Several shRNA sequences targeting Kv4.1 were obtained from the RNAi Consortium and screened to determine the efficacy in reducing Kv4.1 expression. For screening, tsA201 cells were cotransfected using PepMute (Signagen) with a cDNA construct encoding Kv4.1eYFP (obtained from A. Butler, Washington University) and one of the Kv4.1-targeted shRNAs or the nontargeted control shRNA (5'-CAACAAGATGAAGAGCACCAA-3'), which targets a variant of green fluorescent protein (turboGFP). Approximately $48 \mathrm{~h}$ later, cell lysates were prepared, fractionated by SDS-PAGE, transferred to polyvinylidene fluoride (PVDF) membranes and probed for GFP (Millipore, polyclonal anti-GFP, 1:1000) and Kv4.1 (Abcam polyclonal anti-Kv4.1, 1:500). Blots were also probed with an $\alpha$-tubulin antibody (Abcam; monoclonal anti- $\alpha$-tubulin, $1: 10,000)$ to verify equal protein loading. The efficiency of the knockdown of Kv4.1-eGFP by each Kv4.1-targeted shRNA was quantified by densitometry. The shRNA sequence (5'-GCGGAGTGTGATGAGCCTTAT-3') producing the largest reduction of Kv4.1-eGFP expression in tsA-201 cells was also evaluated for specificity. In these experiments, tsA201 cells were cotransfected with cDNA constructs encoding Kv4.1-eYFP, Kv4.2-eYFP, or Kv4.3 and either the Kv4.1-targeted shRNA or the nontargeted shRNA. Approximately $48 \mathrm{~h}$ after the transfections, lysates were fractionated by SDSPAGE, transferred to PVDF membranes and probed for Kv4.1 (Abcam, polyclonal anti-Kv4.1, 1:500), Kv4.2 (NeuroMab, monoclonal anti-Kv4.2, 1:500) or Kv4.3 (NeuroMab, monoclonal anti-Kv4.3, 1:500).

The Kv4.1-targeted and the nontargeted shRNA 21nucleotide sense sequences were synthesized into the corresponding 97-nucleotide miRNA-adapted shRNA oligonucleotides, containing sense and antisense sequences linked by a hairpin loop. Forward and reverse strands were annealed and cloned, in a microRNA (human miR30) context, in the 3'-untranslated region of eGFP in the pPRIME vector (Norris et al., 2010). The entire eGFPshRNA cassette was then inserted into a viral shuttle vector with a synapsin (SYN) promoter and adeno- 
associated virus serotype 8 (AAV8) was generated by the Hope Center Virus Core Facility.

\section{Stereotaxic virus injections in the SCN}

Under sterile conditions, adult (four- to nine-week) male WT C57BL/6 mice were anesthetized with isofluorane and secured in a stereotaxic head frame (Kopf Instruments). Eye ointment was applied to keep the eyes moist during the surgery. Heads were shaved, and Betadine was applied to cleanse and sterilize the shaved region. An incision was made along the midline and the skin was pulled back to expose the skull. For acute knockdown experiments, $1.2 \mu \mathrm{l}$ of the nontargeted shRNA- or the Kv4.1targeted shRNA-expressing AAV8 was injected into each side of the bilateral SCN (coordinates: $0.3 \mathrm{~mm}$ rostral to bregma, $0.1 \mathrm{~mm}$ left and right to midline, and $5.6 \mathrm{~mm}$ ventral to pial surface). The injection syringe (Hamilton) delivered the virus at a constant rate of $0.1 \mu \mathrm{l} / \mathrm{min}$ using a syringe pump (KD Scientific). The syringe was left in place for $\sim 5$ min after the injection was complete to minimize the upward reflux of the solution during the removal of the needle. Silk sutures were used to close the incision. Animals were given an intraperitoneal injection of Rimadyl $(0.1 \mathrm{ml}$ of $0.05 \mathrm{mg} / \mathrm{ml}$, Pfizer) and allowed to recover from the anesthesia on a heating pad maintained at $37^{\circ} \mathrm{C}$.

\section{Preparation of acute SCN slices}

Acute SCN slices $(300 \mu \mathrm{m})$ were prepared from adult (6- to 12-week) male mice maintained in either a standard (lights on at 7 A.M. and lights off at 7 P.M.) or a reversed 12/12 h light/dark (LD) cycle (Granados-Fuentes et al., 2012). Zeitgeber times (ZTs) are indicated: ZTO corresponds to the time of lights on and ZT12 to the time of lights off in the animal facility. Daytime slices were routinely prepared at ZT5 from mice maintained in the standard LD cycle and nighttime slices were prepared at ZT15 from mice maintained in a reversed (i.e., lights on at 7 P.M. and lights off at 7 A.M.) LD cycle. For the preparation of daytime slices, brains were rapidly removed (in the light) from animals anesthetized with $1.25 \%$ Avertin (Acros Organics, 2,2,2-tribromoethanol and tert-amyl alcohol in $0.9 \% \mathrm{NaCl} ; 0.025 \mathrm{~mL} / \mathrm{g}$ body weight) and placed in ice-cold cutting solution containing: $240 \mathrm{mM}$ sucrose, 2.5 $\mathrm{mM} \mathrm{KCl}, 1.25 \mathrm{mM} \mathrm{NaH}_{2} \mathrm{PO}_{4}, 25 \mathrm{mM} \mathrm{NaHCO}_{3}, 0.5 \mathrm{mM}$ $\mathrm{CaCl}_{2}$, and $7 \mathrm{mM} \mathrm{MgCl}_{2}$, saturated with $95 \% \mathrm{O}_{2} / 5 \% \mathrm{CO}_{2}$. For the preparation of nighttime slices, animals in the reversed LD cycle were removed from their cages at ZT15 under infrared illumination (to avoid exposure to visible light during the preparation of acute SCN slices), anesthetized with isoflorane and enucleated using previously described procedure (Aton et al., 2004; Hattar et al., 2006; Hermanstyne et al., 2016). Following an intraperitoneal injection of Rimadyl $(0.1 \mathrm{ml}$ of $0.05 \mathrm{mg} / \mathrm{ml}$, Pfizer), each animal was allowed to recover from the anesthesia (for $\sim 1$ h) before transport to the laboratory for the preparation of slices. At ZT16, animals were anesthetized with $1.25 \%$ Avertin; brains were rapidly removed and placed in icecold cutting solution. For all experiments, coronal slices $(300 \mu \mathrm{m})$ were cut on a Leica VT1000 S vibrating blade microtome (Leica Microsystems) and incubated in a holding chamber with oxygenated artificial cerebrospinal fluid
(ACSF) containing: $125 \mathrm{mM} \mathrm{NaCl}, 2.5 \mathrm{mM} \mathrm{KCl}, 1.25 \mathrm{mM}$ $\mathrm{NaH}_{2} \mathrm{PO}_{4}, 25 \mathrm{mM} \mathrm{NaHCO}$, $2 \mathrm{mM} \mathrm{CaCl}, 1 \mathrm{mM} \mathrm{MgCl}$, and $25 \mathrm{mM}$ dextrose $\left(\sim 310 \mathrm{mOsmol} \mathrm{I}{ }^{-1}\right)$, saturated with $95 \% \mathrm{O}_{2} / 5 \% \mathrm{CO}_{2}$, at room temperature $\left(23-25^{\circ} \mathrm{C}\right)$ for at least $1 \mathrm{~h}$ before transfer to the recording chamber.

\section{Electrophysiological recordings}

Whole-cell voltage- and current-clamp recordings were obtained from SCN neurons in slices prepared during the day (ZT7-ZT12) or at night (ZT19-ZT24) at room temperature $\left(23-25^{\circ} \mathrm{C}\right)$ from WT animals and from animals injected with the nontargeted shRNA- or the Kv4.1-targeted shRNA-expressing AAV8. SCN neurons were visually identified in slices using differential interference contrast optics with infrared illumination. Slices were perfused continuously with ACSF saturated with $95 \% \mathrm{O}_{2} / 5 \% \mathrm{CO}_{2}$. For voltage-clamp recordings, the ACSF also contained tetraethylammonium $(3 \mathrm{mM}), \mathrm{CdCl}_{2}(0.1 \mathrm{mM})$, and tetrodotoxin (150 nM). Recording pipettes ( $3-5 \mathrm{M} \Omega$ ) contained: $144 \mathrm{mM}$ K-gluconate, $10 \mathrm{mM}$ HEPES, $3 \mathrm{mM} \mathrm{MgCl}$, $4 \mathrm{mM}$ MgATP, 0.2 mM EGTA, and 0.5 mM NaGTP (pH 7.3; 300 mOsmol $\mathrm{I}^{-1}$ ). Voltage-clamp paradigms were generated and data were collected using a Multiclamp 700B patch clamp amplifier (Molecular Devices) interfaced to a Dell personal computer with a Digidata 1332 and the pCLAMP 10 software package (Molecular Devices). Tip potentials were zeroed before membrane-pipette seals were formed. Following formation of a $G \Omega$ seal and establishing the whole-cell configuration, membrane capacitances and series resistances were compensated electronically. Series resistances before compensation were in the range of $15-20 \mathrm{M} \Omega$, and were routinely corrected by $70-80 \%$. If the series resistance changed $\geq 20 \%$ during the recording, the experiment was stopped and acquired data from that cell were not included in the analyses. Voltage signals were acquired at $20 \mathrm{kHz}$, filtered at $10 \mathrm{kHz}$, and stored for offline analysis. Whole-cell membrane capacitances were determined from analyses of capacitative currents elicited by brief $(25 \mathrm{~ms})$ voltage steps $( \pm 20 \mathrm{mV})$ from the holding potential $(-70 \mathrm{mV})$.

Rapidly activating and inactivating Kv currents, $I_{A}$, were isolated using a two-step voltage-clamp protocol (Norris and Nerbonne, 2010; Granados-Fuentes et al., 2012; Granados-Fuentes et al., 2015). Briefly, in each cell, whole-cell Kv currents, evoked in response to $2 \mathrm{~s}$ depolarizing voltage steps to potentials between -40 and +30 $\mathrm{mV}$ (in 10-mV increments) from a holding potential of -70 $\mathrm{mV}$, were first recorded. Currents were then recorded again with a prepulse paradigm that included a brief (60 $\mathrm{ms}$ ) step to $-10 \mathrm{mV}$ before the $2 \mathrm{~s}$ depolarizing voltage steps to potentials between -40 and $+30 \mathrm{mV}$ (in 10-mV increments). Off-line subtraction of the Kv currents recorded with the prepulse paradigm from the currents evoked without the prepulse provided $I_{A}$.

In separate experiments, the voltage dependences of activation and steady-state inactivation of $\mathrm{I}_{\mathrm{A}}$ in nontargeted shRNA- and Kv4.1-targeted shRNA-expressing SCN neurons were examined. To generate the activation plots, $I_{A}$ was isolated using a two-step protocol, as described above. In these experiments, however, Kv cur- 
Table 1. Resting and active membrane properties of WT, nontargeted-, and Kv4.1-targeted shRNA-expressing SCN neurons during the day and at night

\begin{tabular}{|c|c|c|c|c|c|c|c|c|}
\hline & & $\begin{array}{c}R_{\text {in }} \\
(M \Omega)\end{array}$ & $\begin{array}{c}\text { Firing rate } \\
(\mathrm{Hz})\end{array}$ & $\begin{array}{r}\mathrm{ISI} \\
(\mathrm{ms}) \\
\end{array}$ & $\begin{array}{c}\mathrm{V}_{\mathrm{r}} \\
(\mathrm{mV})\end{array}$ & $\begin{array}{l}\text { APT } \\
(\mathrm{mV})\end{array}$ & $\begin{array}{l}\mathrm{APD}_{50} \\
\text { (ms) }\end{array}$ & $\begin{array}{l}\text { AHP } \\
(\mathrm{mV})\end{array}$ \\
\hline \multirow{3}{*}{ 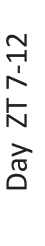 } & WT & $\begin{array}{c}1957 \pm 200^{1} \\
n=19\end{array}$ & $\begin{array}{c}3.5 \pm 0.5^{1,4} \\
n=21\end{array}$ & $\begin{array}{c}515 \pm 143^{8} \\
n=21\end{array}$ & $\begin{array}{c}-40.5 \pm 0.7 \\
n=21\end{array}$ & $\begin{array}{c}-30.5 \pm 0.8 \\
n=21\end{array}$ & $\begin{array}{c}3.2 \pm 0.3 \\
n=21\end{array}$ & $\begin{array}{c}-13.4 \pm 1.4 \\
n=21\end{array}$ \\
\hline & $\begin{array}{c}\text { Non-targeted } \\
\text { shRNA }\end{array}$ & $\begin{array}{c}1613 \pm 191^{2} \\
n=17\end{array}$ & $\begin{array}{c}3.1 \pm 0.5^{2,5} \\
\mathrm{n}=17\end{array}$ & $\begin{array}{c}531 \pm 90^{9} \\
\mathrm{n}=17\end{array}$ & $\begin{array}{c}-43.3 \pm 0.9 \\
n=17\end{array}$ & $\begin{array}{c}-26.9 \pm 1.6 \\
n=16\end{array}$ & $\begin{array}{c}3.2 \pm 0.3 \\
n=16\end{array}$ & $\begin{array}{c}-17.3 \pm 2.2 \\
n=16\end{array}$ \\
\hline & $\begin{array}{c}\text { Kv4.1-targeted } \\
\text { shRNA }\end{array}$ & $\begin{array}{c}1633 \pm 104^{3} \\
n=19\end{array}$ & $\begin{array}{c}6.4 \pm 0.5^{3,4,5} \\
n=24\end{array}$ & $\begin{array}{c}172 \pm 15^{8,9} \\
\mathrm{n}=24\end{array}$ & $\begin{array}{c}-41.4 \pm 1.2 \\
n=24\end{array}$ & $\begin{array}{c}-28.7 \pm 1.4 \\
n=24\end{array}$ & $\begin{array}{c}2.9 \pm 0.3 \\
n=24\end{array}$ & $\begin{array}{c}-14.7 \pm 2.0 \\
n=24\end{array}$ \\
\hline \multirow{3}{*}{ 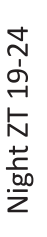 } & WT & $\begin{array}{c}1396 \pm 160^{1,6} \\
n=15\end{array}$ & $\begin{array}{c}1.8 \pm 0.4^{1,6} \\
n=17\end{array}$ & $\begin{array}{c}866 \pm 174^{10} \\
n=17\end{array}$ & $\begin{array}{c}-43.9 \pm 1.2 \\
n=17\end{array}$ & $\begin{array}{c}-27.9 \pm 1.4 \\
n=17\end{array}$ & $\begin{array}{c}2.7 \pm 0.2 \\
n=17\end{array}$ & $\begin{array}{c}-17.4 \pm 1.8 \\
n=17\end{array}$ \\
\hline & $\begin{array}{l}\text { Non-targeted } \\
\text { shRNA }\end{array}$ & $\begin{array}{c}1143 \pm 93^{2,7} \\
n=24\end{array}$ & $\begin{array}{c}1.6 \pm 0.3^{2,7} \\
n=27\end{array}$ & $\begin{array}{c}999 \pm 182^{7} \\
n=26\end{array}$ & $\begin{array}{c}-42.6 \pm 1.1 \\
n=26\end{array}$ & $\begin{array}{c}-28.6 \pm 1.1 \\
n=26\end{array}$ & $\begin{array}{c}3.4 \pm 0.4 \\
n=26\end{array}$ & $\begin{array}{c}-16.9 \pm 1.7 \\
n=26\end{array}$ \\
\hline & $\begin{array}{c}\text { Kv4.1-targeted } \\
\text { shRNA }\end{array}$ & $\begin{array}{c}2256 \pm 166^{3,6,7} \\
n=23\end{array}$ & $\begin{array}{c}4.3 \pm 0.6^{3,6,7} \\
n=26\end{array}$ & $\begin{array}{c}386 \pm 63^{7,10} \\
n=26\end{array}$ & $\begin{array}{c}-39.9 \pm 0.8 \\
n=26\end{array}$ & $\begin{array}{c}-26.9 \pm 1.4 \\
n=26\end{array}$ & $\begin{array}{c}3.5 \pm 0.3 \\
n=26\end{array}$ & $\begin{array}{c}-15.4 \pm 2.1 \\
n=26\end{array}$ \\
\hline
\end{tabular}

Values are means $\pm \mathrm{SEM} ; n$, number of cells; $\mathrm{R}_{\mathrm{in}}$, input resistance; ISI, interspike interval; $\mathrm{V}_{\mathrm{r}}$, resting membrane potential; APT, action potential threshold; $\mathrm{APD}_{50}$, action potential duration at $50 \%$ repolarization; AHP, afterhyperpolarization amplitude. ${ }^{1}$ Values in WT neurons during the day and at night $\left({ }^{1} p<0.05\right)$ are significantly different. ${ }^{2}$ Values in nontargeted shRNA-expressing neurons during the day and at night $\left({ }^{2} p<0.05\right)$ are significantly different. ${ }^{3}$ Values in Kv4.1-targeted shRNA-expressing neurons during the day and at night $\left({ }^{3} p<0.01\right)$ are significantly different. ${ }^{4-9}$ Values in WT and nontargeted shRNA-expressing neurons during the day $\left({ }^{4} p<0.0006 ;{ }^{5} p<0.0001 ;{ }^{8,9} p<0.05\right)$ are significantly different from Kv4.1-targeted shRNA-expressing neurons and at night $\left({ }^{6} p<0.0006 ;{ }^{7} p<0.0001 ;{ }^{10} p<0.01\right)$.

rents were evoked in response to test potentials from -65 $\mathrm{mV}$ to $+35 \mathrm{mV}$ (in 5-mV increments) from a holding potential of $-70 \mathrm{mV}$. In each cell, $\mathrm{I}_{\mathrm{A}}$ conductances $\left(\mathrm{G}_{\mathrm{IA}}\right)$ at each test potential were calculated and normalized to the maximal conductance $\left(G_{1 A \max }\right)$. Mean \pm SEM normalized $I_{A}$ conductances $\left(G_{I A} / G_{I A m a x}\right)$ were plotted as a function of the test potential and fitted using the Boltzmann equation, $G_{I A} / G_{I A \text {, max }}=1+e^{[(V a-V m) / k]}$, where $V_{a}$ is the membrane potential of half-maximal activation and $k$ is the slope factor.

To determine the voltage dependence of steady-state inactivation of $\mathrm{I}_{\mathrm{A}}$, a three-step voltage-clamp paradigm was used. In each cell, Kv currents evoked at $+10 \mathrm{mV}$ from different conditioning voltages, ranging from -120 to $-20 \mathrm{mV}$ (in 5-mV increments). In each cell, $\mathrm{I}_{\mathrm{A}}$ evoked from each conditioning voltage was measured and normalized to the maximum current evoked from the most hyperpolarized $(-100 \mathrm{mV})$ membrane potential (in the same cell). Mean \pm SEM normalized current amplitudes $\left(\mathrm{I}_{A} / \mathrm{I}_{\text {Amax }}\right)$ were plotted as a function of the conditioning voltage and fitted using the Boltzmann equation, $\mathrm{I}_{\mathrm{A}} / \mathrm{I}_{\mathrm{A} \text {, max }}=$ $1 /\left(1+e^{[(\mathrm{Vh}-\mathrm{Vm}) / \mathrm{k}]}\right)$, where $\mathrm{V}_{\mathrm{h}}$ in the membrane potential at half-maximal inactivation and $k$ is the slope factor.

Whole-cell current-clamp recordings were obtained using pipettes (4-7 M $\mathrm{M}$ ) containing: $144 \mathrm{mM} \mathrm{K}$-gluconate, $10 \mathrm{mM}$ HEPES, $3 \mathrm{mM} \mathrm{MgCl}_{2}, 4 \mathrm{mM}$ MgATP, $0.2 \mathrm{mM}$ EGTA, and $0.5 \mathrm{mM} \mathrm{NaGTP} \mathrm{(pH} \mathrm{7.3;} 300 \mathrm{mOsm}$ ). Slices were perfused continuously with ACSF containing $20 \mu \mathrm{M}$ Gabazine (Tocris Bioscience) and saturated with 95\% $\mathrm{O}_{2} / 5 \% \mathrm{CO}_{2}$. A loose patch, cell-attached recording was first obtained and spontaneous activity was recorded for $\sim 1$ min (Hermanstyne et al., 2016). Following the formation of a $\mathrm{G} \Omega$ seal, the whole-cell configuration was established and whole-cell membrane capacitances and series resistances were compensated. Whole-cell spontaneous firing activity was then recorded for $\sim 1 \mathrm{~min}$. Access resistances were 15-20 M $\Omega$, and data acquisition was terminated if the access resistance increased (20\%) during the experiment. Voltage signals were acquired at $100 \mathrm{kHz}$, filtered at $10 \mathrm{kHz}$ and stored for offline analysis. Input resistances $\left(R_{\text {in }}\right)$ were determined by measuring the steady-state voltage changes produced by $\pm 5 \mathrm{pA}$ current injections from a hyperpolarized membrane potential. The voltage threshold for action potential generation (APT) in each cell was determined as the point during the upstroke (depolarizing phase) of the action potential at which the second derivative of the voltage was zero. Afterhyperpolarization amplitudes (AHPs) were measured in each cell as the difference between the APT and the most negative membrane potential. Action potential durations were measured at $50 \%$ repolarization $\left(A P D_{50}\right) . V_{r}$ were determined from phase plots of the first derivative of the membrane potential (dV/dT) plotted versus the membrane potential $(\mathrm{mV})$. Statistical analyses were performed using one-way ANOVA with Newman-Kuels post hoc pairwise comparisons or two-sample Kolmogorov-Smirnov test. All data were analyzed using GraphPad Prism software with the exception of the cumulative distribution plots, which were analyzed using OriginLab with the twosample Kolmogorov-Smirnov test. Statistical significance was set at $P<0.05 ; P$ values are reported in the text, Table 1 and figure legends. The structure of the dataset and the statistical power for each analysis are provided in Table 2. The letters $(a-m)$ in Table 2 represent the statistical analyses performed and correspond to the superscripts presented in the Results section.

\section{Extracellular multielectrode array recordings}

Dispersed SCN neuron cultures were prepared as previously described (Herzog et al., 1998). Briefly, SCN were 
Table 2. Statistical table

\begin{tabular}{llll}
\hline & Data structure & Type of test & Power \\
$\mathrm{a}$ & Normal distribution & One-way ANOVA & $F$ statistic: 14.2 \\
$\mathrm{~b}$ & Normal distribution & One-way ANOVA & $F$ statistic: 7.54 \\
$\mathrm{c}$ & Normal distribution & One-way ANOVA & $F$ statistic: 52.15 \\
$\mathrm{~d}$ & Normal distribution & One-way ANOVA & $F$ statistic: 1.99 \\
$\mathrm{e}$ & Normal distribution & One-way ANOVA & $F$ statistic: 0.53 \\
$\mathrm{f}$ & Normal distribution & One-way ANOVA & $F$ statistic: 1.11 \\
$\mathrm{~g}$ & Normal distribution & One-way ANOVA & $F$ statistic: 0.37 \\
$\mathrm{~h}$ & Normal distribution & One-way ANOVA & $F$ statistic: 17.9 \\
$\mathrm{i}$ & Continuous distribution & Kolmogorov-Smirnov & $D$ statistic: 0.4 \\
$\mathrm{j}$ & Non-normal distribution & Mann-Whitney-Wilcoxon test & $U$ statistic: 819 \\
$\mathrm{k}$ & Normal distribution & One-way ANOVA & $F$ statistic: 4.03 \\
$\mathrm{l}$ & Normal distribution & Student's $t$ test & $T$ statistic: 5.68 \\
$\mathrm{~m}$ & Normal distribution & Student's $t$ test & $T$ statistic: 3.04 \\
$\mathrm{n}$ & Continuous distribution & Kolmogorov-Smirnov & $D$ statistic: 0.6 \\
\hline
\end{tabular}

removed from postnatal day 4 (P4) PER2 ${ }^{\mathrm{LUC}}$ mice, and $(300 \mu \mathrm{m})$ coronal slices were cut on a Vibratome (OTS5000; Electron Microscopy Sciences). Four to six SCN punches ( $1 \mathrm{~mm}$ diameter) were taken from each slice and enzymatically dissociated using papain. Isolated neurons were plated at a density of 10,000 neurons $/ \mathrm{mm}^{2}$ on polyD-lysine and laminin-coated multielectrode arrays (sixty 30- $\mu \mathrm{m}$ - diameter electrodes, Multichannel Systems). Cultures were maintained in $1 \mathrm{ml}$ Dulbeccos Modified Eagles Medium (DMEM) supplemented with $10 \%$ fetal calf serum (Life Technologies) at $37^{\circ} \mathrm{C}$ in a $95 \% \mathrm{O}_{2} / 5 \% \mathrm{CO}_{2}$ incubator. For knockdown experiments, cultures were incubated with the nontargeted shRNA- or the Kv4.1-targeted shRNA-expressing AAV8 for $3 \mathrm{~d}$. Extracellular action potential recordings were obtained from dispersed SCN neurons for at least $5 \mathrm{~d}$, as previously described (Aton et al., 2005). Single-cell action potentials were digitized in real-time (MC-Rack Software, Multichannel Systems) and discriminated offline using principal component analysis (Offline Sorter). NeuroExplorer software was used to bin the firing rates in 10 min intervals. Firing rate rhythms were fitted with a damped sine function (Chronostar 2.0; Maier et al., 2009) and data with correlation coefficients $\geq 0.8$ and a period of $18-32 \mathrm{~h}$ were defined as circadian. Repetitive firing rates at the peak and trough of activity in Kv4.1 shRNA- and nontargeted shRNA-expressing SCN neurons were averaged over $3 \mathrm{~d}$ and compared using one-way ANOVA with Newman-Kuels post hoc pairwise comparisons.

\section{Real-time gene expression (PER2::LUC) recordings}

Bioluminescence was recorded from SCN slices prepared from P4 PER2 ${ }^{\mathrm{LUC}}$ mice housed in a standard 12:12 $\mathrm{h}$ LD cycle. For the preparation of slices, brains were quickly removed and chilled in Hanks' balanced salt solution (HBSS), supplemented with 0.01 M HEPES, 100 $\mathrm{U} / \mathrm{ml}$ penicillin, $0.1 \mathrm{mg} / \mathrm{ml}$ streptomycin, and $4 \mathrm{mM}$ $\mathrm{NaHCO}_{3}$. Vibratome slices $(300 \mu \mathrm{m})$ were cut and placed on $0.4 \mathrm{~mm}$ membrane inserts (Millipore) in $35-\mathrm{mm}$ Petri dishes (BD Biosciences) with 1-ml HEPES-buffered DMEM supplemented with $10 \%$ newborn calf serum (Invitrogen) and $0.1 \mathrm{mM}$ beetle luciferin (Biosynth). Immediately after plating, slices were transduced with either the Kv4.1-targeted shRNA- or the nontargeted shRNA- expressing AAV8. Virus-containing media was removed after $3 \mathrm{~d}$. After 2 weeks in culture, Petri dishes were sealed with vacuum grease and placed under photomultiplier tubes (HC135-11MOD; Hamamatsu) at $36^{\circ} \mathrm{C}$ in the dark. Bioluminescence was recorded in 10-min bins for at least $5 \mathrm{~d}$. The period of PER2 ${ }^{\mathrm{LUC}}$ expression was determined using Chronostar and compared using a one-way ANOVA followed by a Tukey post hoc test.

\section{Analyses of locomotor activity}

Bilateral injections (1.2 $\mu \mathrm{l}$ total volume) of the nontargeted shRNA- or the Kv4.1 shRNA-expressing AAV8 were made in adult (8-12 week-old) WT male mice (during the day). Approximately $10 \mathrm{~d}$ after surgery, animals were placed individually in cages equipped with running wheels in light-tight chambers illuminated with fluorescent bulbs $\left(2.4 \pm 0.5 \times 10^{18}\right.$ photons $/ \mathrm{s} * \mathrm{~m}^{2}$; General Electric). Wheelrunning activity was recorded in 6-min bins (Clocklab Actimetrics) for 5-10 d in a 12:12 h LD cycle followed, by $15-20 \mathrm{~d}$ in constant darkness (DD). The period of behavioral rhythmicity of each mouse was determined using $\chi^{2}$ periodogram analysis (Sokolove and Bushell, 1978) from continuous recordings of $10 \mathrm{~d}$ in DD (Clocklab). Rhythmicity was considered statistically significant if the $\chi^{2}$ periodogram value exceeded the $99.9 \%$ confidence interval ( $\mathrm{pp}$ value).

\section{Results}

\section{Efficient and specific shRNA-mediated knockdown of $\mathrm{Kv4.1}$}

An RNA interference-based strategy was developed to allow the acute in vivo knockdown of Kv4.1 in adult mouse SCN neurons. Several shRNA sequences targeted against Kv4.1 were screened for effectiveness in reducing Kv4.1 expression in tsA201 cells as described in Methods and Materials. The specificity of the shRNA that provided the greatest ( $\sim 80 \%)$ knockdown (see Methods and Materials) was also evaluated in tsA201 cells cotransfected with the Kv4.1-targeted shRNA or the nontargeted shRNA together with a cDNA construct encoding Kv4.1, Kv4.2 or Kv4.3. As illustrated in Figure 1, the Kv4.1-targeted shRNA was effective in reducing the expression of Kv4.1 (Fig. 1A), whereas neither Kv4.2 (Fig. 1B) nor Kv4.3 (Fig. 
A

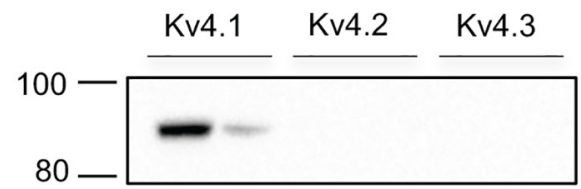

anti-

Kv4.1

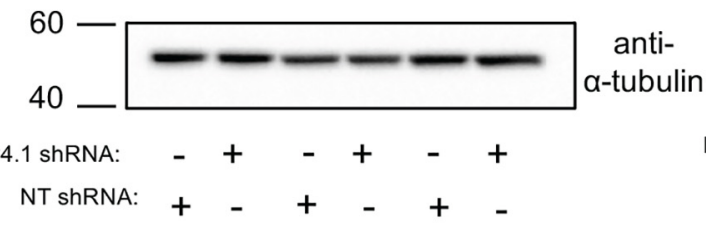

C

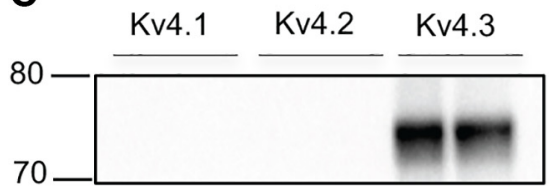

anti-

Kv4.3

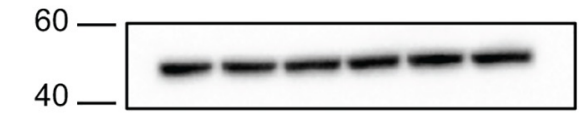

anti-

a-tubulir
B
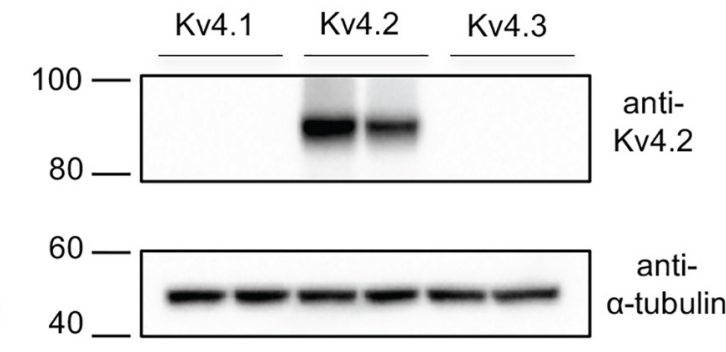

Kv4.1 shRNA: $\quad$ - $+\quad-\quad+\quad-\quad+$

NT ShRNA: $+\quad-\quad+\quad-\quad+\quad-$

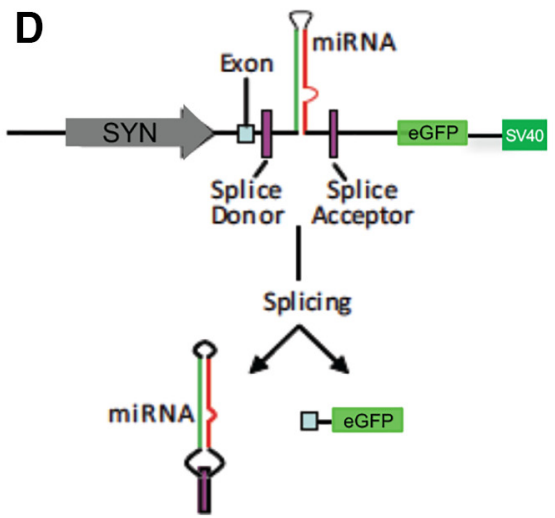

\section{E}

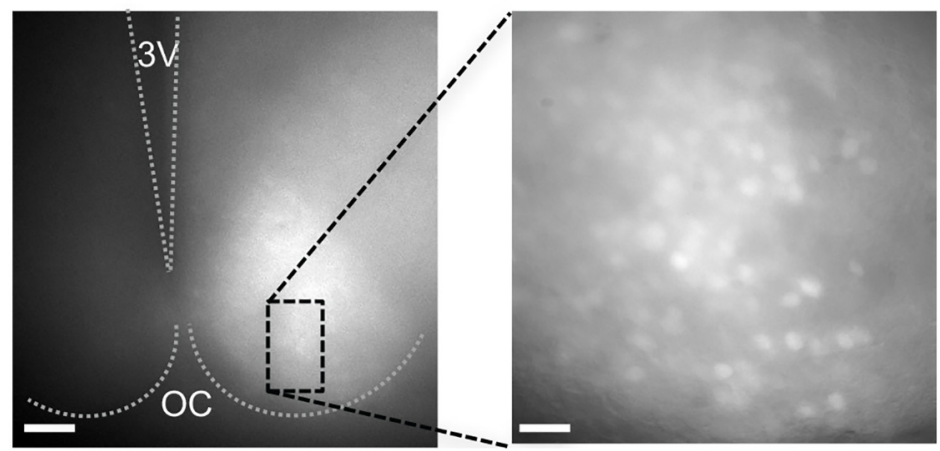

Figure 1. Validation of Kv4.1-targeted shRNAs. A-C, The Kv4.1-eYFP, Kv4.2-eYFP, or Kv4.3 construct was coexpressed with either the Nontargeted (NT) shRNA or the Kv4.1-targeted shRNA in tsA-201 cells. Approximately $48 \mathrm{~h}$ later, lysates were prepared, fractionated by SDS-PAGE, transferred to PVDF membranes, and probed with an anti-Kv4.1, anti-Kv4.2, or anti-Kv4.3 antibody. Blots were also reprobed with an anti- $\alpha$ tubulin ( $\alpha$-tubulin) antibody to verify equal loading of proteins. The Kv4.1-targeted shRNA markedly reduced the expression of Kv4.1, compared with the nontargeted shRNA $(\boldsymbol{A})$, whereas neither Kv4.2 (B) nor Kv4.3 (C) expression was measurably affected. $\boldsymbol{D}$, The Kv4.1-targeted and the nontargeted shRNAs were cloned, in a microRNA (miR30) context, between splice donor and acceptor sequences in an artificial intron downstream of the SYN promoter and upstream of the reporter (eGFP) cDNA (Norris et al., 2010). E, An acute SCN slice, prepared from an adult mouse $27 \mathrm{~d}$ following a unilateral injection of the Kv4.1-targeted shRNA-expressing AAV8 into the right hemisphere, is shown. In the left panel, a low-magnification fluorescence image reveals eGFP expression in the right hemisphere only. The third ventricle (3V) and the optic chiasm (OC) are marked. In the higher magnification image on the right, virally-transduced eGFP-expressing neurons are evident throughout the SCN. Scale bars: 200 and $50 \mu \mathrm{m}$ in the left and right panels, respectively.

1C) expression was measurably affected by coexpression with the Kv4.1-targeted shRNA.

The Kv4.1-targeted shRNA and the nontargeted shRNA were cloned (separately), in a microRNA (human miR30) context, into a plasmid containing a SYN promoter and eGFP (Norris et al., 2010). Using this strategy (Fig. 1D), the shRNA and GFP are processed from a single transcript.
For experiments, adeno-associated viruses serotype 8 (AAV8) were generated as described in Methods and Materials. Stereotaxic injections of the Kv4.1-targeted shRNA- or the nontargeted shRNA-expressing AAV8 were made into the SCN of 6- to 12-week-old mice. Transduced SCN neurons in acute SCN slices were visually identified by the presence of eGFP (Fig. 1E). 


\section{Knockdown of Kv4.1 attenuates IA in SCN neurons}

Whole-cell voltage-clamp recordings were obtained from eGFP-expressing SCN neurons in acute slices prepared from animals injected with either the Kv4.1-targeted shRNA-or the nontargeted shRNA-expressing AAV8. Consistent with previous studies (Itri et al., 2010; Granados-Fuentes et al., 2012; Granados-Fuentes et al., 2015), I $I_{A}$ was readily identified in every cell examined (Fig. $2 A-D)$. To quantify the amplitudes/densities of $\mathrm{I}_{\mathrm{A}}$, a twostep voltage-clamp paradigm, which is illustrated below the current records in Fig. 2A1-A2, was used. Offline subtraction of the current records obtained with the prepulse from the controls provided $\mathrm{I}_{\mathrm{A}}$ (see Methods and Materials). The amplitudes/densities of $\mathrm{I}_{\mathrm{A}}$ in $\mathrm{SCN}$ neurons expressing the Kv4.1-targeted shRNA were $35 \%-50 \%$ lower than those measured in SCN neurons transduced with the nontargeted shRNA-expressing AAV8 (Fig. $2 A 3-D 3)^{\mathrm{k}}$. At $+30 \mathrm{mV}$, for example, mean $\mathrm{I}_{\mathrm{A}}$ densities were significantly ( $\rho=0.04)$ lower during the day and at night in Kv4.1-targeted shRNA-expressing SCN neurons (day: $80.3 \pm 11.8 \mathrm{pA} / \mathrm{pF}$; night: $55.3 \pm 7.7 \mathrm{pA} / \mathrm{pF}$ ) than in nontargeted shRNA-expressing SCN neurons (day: $121.7 \pm 10.2$ pA/pF; night: $120.6 \pm 16.5$ pA/pF; Fig. $2 F)^{\mathrm{k}}$. Interestingly, the knockdown of Kv4.1 resulted in a greater effect on $\mathrm{I}_{\mathrm{A}}$ density at night than during day (see Discussion).

Additional experiments were completed (as described in Materials and Methods) to examine the voltage dependences of activation and steady-state inactivation of $\mathrm{I}_{\mathrm{A}}$ in Kv4.1-targeted shRNA- and nontargeted shRNAexpressing SCN neurons. The mean \pm SEM normalized data are presented in Figure 2G. The activation curves for $\mathrm{I}_{\mathrm{A}}$ in Kv4.1-targeted shRNA- and nontargeted shRNAexpressing SCN neurons were similar. Note that, although the activation curve for $\mathrm{I}_{\mathrm{A}}$ in $\mathrm{Kv}$ 4.1-targeted shRNAexpressing SCN neurons appears to be shifted slightly compared with the nontargeted shRNA-expressing cells, the $V_{1 / 2}$ activation and $k$ values derived from the fits were not significantly ( $p=0.052$ ) different (Fig. $2 G$ ). The voltage dependences of steady-state inactivation of $\mathrm{I}_{\mathrm{A}}$ in Kv4.1targeted shRNA- and nontargeted shRNA-expressing SCN neurons (Fig. 2G) were also not significantly $(p>$ 0.05) different (see Discussion).

\section{Acute knockdown of Kv4.1 increases spontaneous firing rates in SCN neurons}

Whole-cell current-clamp recordings were obtained from eGFP-expressing SCN neurons in acute slices prepared from animals injected with either the Kv4.1-targeted shRNA- or the nontargeted shRNA-expressing AAV8. Similar to previous reports (Welsh et al., 1995; Pennartz et al., 2002; Hermanstyne et al., 2016), all of the SCN neurons examined were spontaneously active and repetitive firing rates measured in both Kv4.1-targeted shRNAand nontargeted shRNA-expressing cells were significantly $(p<0.04)$ higher in recordings obtained during the day than at night (Fig. $3 A, B)^{\mathrm{a}}$. Importantly, additional recordings from nontransduced, i.e., non-eGFP-expressing, wildtype (WT) SCN neurons in the same slices revealed repetitive firing rates that were not significantly different from those determined in nontargeted shRNA-expressing SCN neurons (Table 1$)^{a}$. The firing rates of SCN neurons transduced with the Kv4.1-targeted shRNA-expressing AAV8, however, were significantly ( $p<0.0001$ ) higher than SCN neurons transduced with the nontargeted shRNA-expressing AAV8 during the day and at night (Fig. $3 B$ and Table 1$)^{\mathrm{a}}$.

Further analyses of the whole-cell current-clamp data revealed that, similar to previous findings in WT SCN neurons (Schaap et al., 1999; Pennartz et al., 2002), there was a marked $(p<0.05)$ day-night difference in the mean $\mathrm{R}_{\mathrm{in}} \mathrm{s}$ of SCN neurons expressing the nontargeted shRNA $(\text { Table } 1)^{\mathrm{b}}$. Compared with nontargeted shRNAexpressing SCN neurons, the acute knockdown of Kv4.1 significantly $(p<0.0001)$ increased the mean $R_{\text {in }}$ at night, but not during the day $(\text { Table } 1)^{\mathrm{b}}$, observations suggesting a physiologic role for Kv4.1-encoded channels in regulating the daily rhythms in the excitability of SCN neurons (see Discussion). In addition, during the day and at night, mean interspike intervals (ISIs) were significantly $(p<$ 0.05) shorter in Kv4.1-targeted shRNA-expressing SCN neurons (Table 1$)^{\mathrm{C}}$. In contrast, the waveforms of individual action potentials recorded from Kv4.1-targeted shRNA- and nontargeted shRNA-expressing SCN neurons were similar (Fig. $3 C$ ). Mean APD $_{50}$ in Kv4.1-shRNAand nontargeted shRNA-expressing SCN neurons, for example, were not significantly $(p>0.05)$ different during the day and at night (Fig. $3 D$ and Table 1). In addition, there were no significant differences between AHPs, APTs, or the $V_{r}$ measured in Kv4.1-targeted shRNA- and nontargeted shRNA-expressing SCN neurons during the day or at night $(\text { Table } 1)^{\mathrm{d}-\mathrm{g}}$.

\section{Acute knockdown of Kv4.1 alters circadian properties of spontaneous electrical activity in SCN neurons}

In parallel with the in vitro slice recordings, we examined the functional consequences of the in vitro knockdown of Kv4.1 expression on circadian rhythms in repetitive firing in dispersed SCN neurons using multielectrode arrays (see Methods and Materials). Continuous recordings of spontaneous firing were obtained over $6 \mathrm{~d}$. As illustrated in Figure 4A, we observed rhythmic electrical activity in SCN neurons transduced with either the Kv4.1-targeted shRNA- or the nontargeted shRNAexpressing AAV8. In SCN neurons transduced with the Kv4.1 shRNA-expressing AAV8 (6.5 $\pm 0.6 \mathrm{~Hz})$, however, the mean firing frequency was significantly $(p=0.007)$ higher during the peak (subjective day) of electrical activity, compared with nontargeted shRNA-expressing (5.2 + $0.5 \mathrm{~Hz}$ ) SCN neurons (Fig. $4 A, B)^{\mathrm{h}}$. During the trough (subjective night), the mean firing frequency was also higher in Kv4.1-targeted shRNA-expressing $(1.1 \pm 0.3 \mathrm{~Hz})$ than in nontargeted shRNA-expressing $(0.3 \pm 0.1 \mathrm{~Hz})$ SCN neurons (Fig. $4 A, B)^{\mathrm{h}}$.

The cumulative distribution plot reveals that, during the peak of electrical activity, $\sim 80 \%$ of the Kv4.1-targeted and nontargeted shRNA-expressing SCN neurons fired at $<10$ and $6 \mathrm{~Hz}$, respectively (Fig. 4C) ${ }^{\mathrm{i}}$. The vast majority $(>80 \%)$ of nontargeted shRNA-expressing SCN neurons 
Day

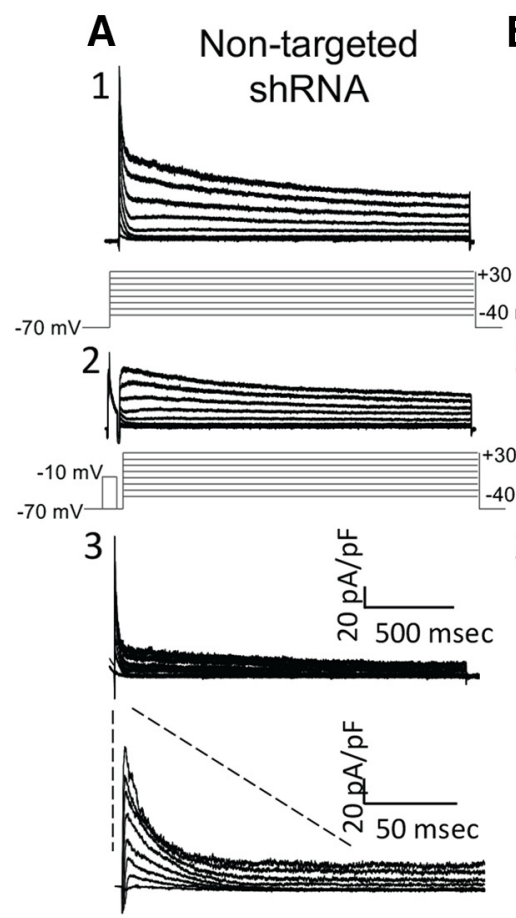

E

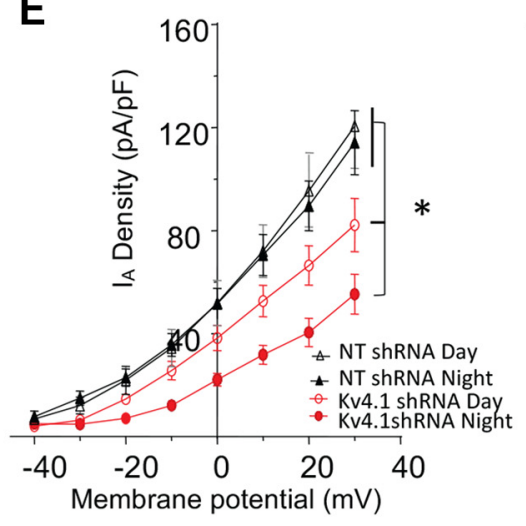

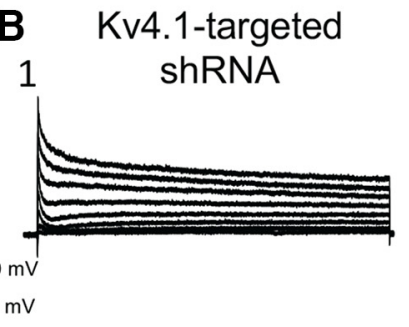
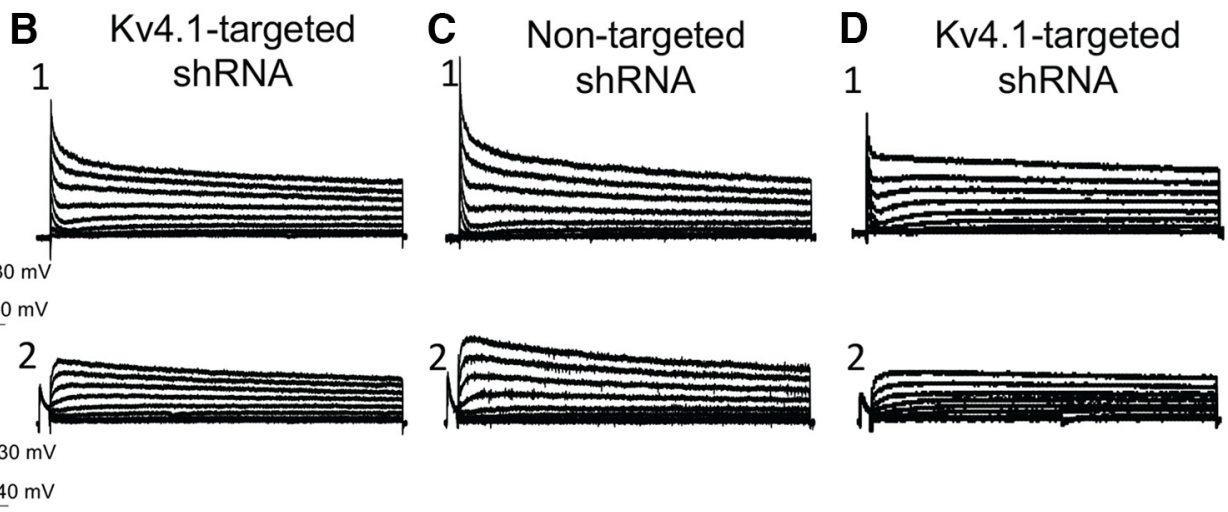

\section{2}

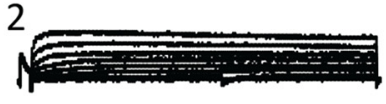

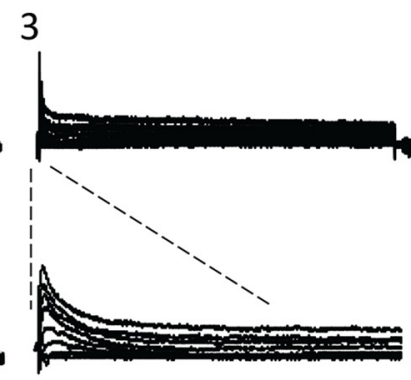

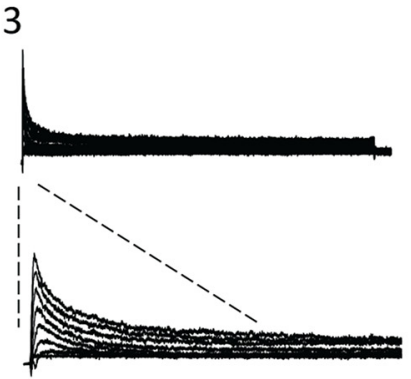

F

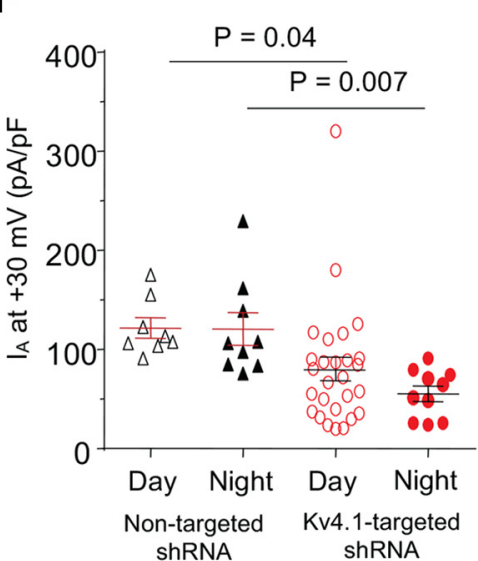

G

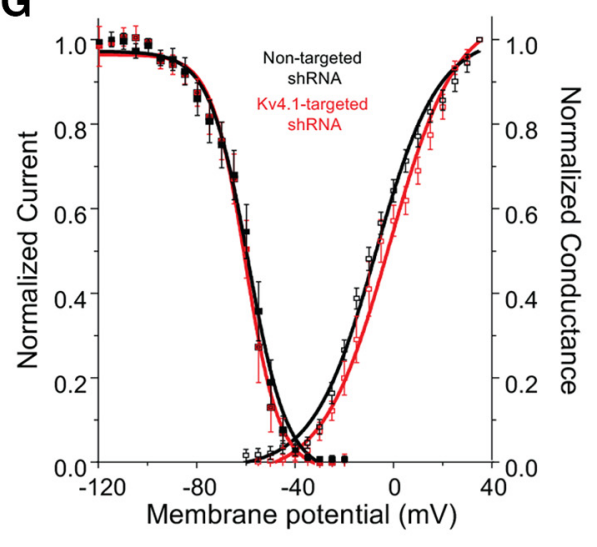

Figure 2. Acute knockdown of $\mathrm{Kv} 4.1$ decreases $A$-type $\mathrm{K}^{+}$currents $\left(\mathrm{I}_{\mathrm{A}}\right)$ in $\mathrm{SCN}$ neurons during the day and at night. $\boldsymbol{A}-\boldsymbol{D}$, Representative whole-cell Kv current recordings, obtained during the day (ZT7-ZT12) or at night (ZT19-ZT24) from eGFPpositive SCN neurons in acute slices prepared from adult animals 14-30 d following injections of the nontargeted shRNA-expressing $(\boldsymbol{A}, \boldsymbol{C})$ or the Kv4.1-targeted shRNA-expressing $(\boldsymbol{B}, \boldsymbol{D}) \mathrm{AAV} 8$, are shown. Whole-cell Kv currents, evoked during (2 s) voltage steps to potentials ranging from -40 to $+30 \mathrm{mV}$ (in 10-mV increments) from a holding potential of $-70 \mathrm{mV}$, were recorded from nontargeted shRNA- and Kv4.1-targeted shRNA-expressing SCN neurons during the day (A1-B1) and at night (C1-D1). A second voltage-clamp paradigm, that included a brief $(60 \mathrm{~ms})$ prepulse to $-10 \mathrm{mV}$ to inactivate $\mathrm{I}_{\mathrm{A}}$, was then presented, and whole-cell $\mathrm{Kv}$ currents in each cell were recorded again (A2-D2). The voltage-clamp paradigms are illustrated (light gray) below the current records. Digital offline subtraction of the recordings with the prepulse $(\boldsymbol{A} 2-\boldsymbol{D} 2)$ from those without the prepulse $(\boldsymbol{A} 1-\boldsymbol{D} 1)$ isolated $\mathrm{I}_{\mathrm{A}}(\boldsymbol{A} \mathbf{A}-\boldsymbol{D} 3)$; the subtracted records are also shown on an expanded time scale. $\boldsymbol{E}, \mathrm{I}_{\mathrm{A}}$ densities at each test potential in each cell were calculated and mean $\pm \mathrm{SEM}$ values are plotted as a function of test potential. $\boldsymbol{F}$, Mean $\pm \mathrm{SEM} \mathrm{I}_{\mathrm{A}}$ densities at $+30 \mathrm{mV}$ were significantly lower in Kv4.1-targeted shRNA-expressing ( $n=10-27$ ), than in nontargeted shRNA-expressing ( $n=8-10)$ SCN neurons during the day and at night; $p$ values (one-way ANOVA) are indicated. G, The activation curves for Kv4.1-targeted shRNA-expressing SCN neurons (open red squares, $n=8$ ) and nontargeted shRNA-expressing SCN neurons (open black squares, $n=12$ ) are not significantly ( $p=0.052$, Student's $t$ test) different $\left(\mathrm{V}_{1 / 2}=-1.8 \pm 3.2 \mathrm{mV}, k=13.5 \pm 1.1\right.$ and $-9.3 \mathrm{mV} \pm 1.3 \mathrm{mV}, k=12.7 \pm 0.8$, respectively). The inactivation curves plotted as the mean \pm SEM normalized current for Kv4.1-targeted shRNA-expressing (filled red squares, $n=8$ ) and nontargeted shRNA-expressing (filled black squares, $n=12$ ) SCN neurons are also shown. The inactivation curve for Kv4.1-targeted shRNAexpressing SCN neurons $\left(\mathrm{V}_{1 / 2}=-60.3 \mathrm{mV} \pm 1.7 \mathrm{mV}\right.$ and $\left.k=7.0 \pm 0.6\right)$ is not significantly $(p>0.05$, Student's $t$ test) different from the nontargeted shRNA-expressing SCN neurons $\left(\mathrm{V}_{1 / 2}=-59.4 \mathrm{mV} \pm 2.1 \mathrm{mV}\right.$ and $\left.k=7.9 \pm 0.7\right)$. 
A

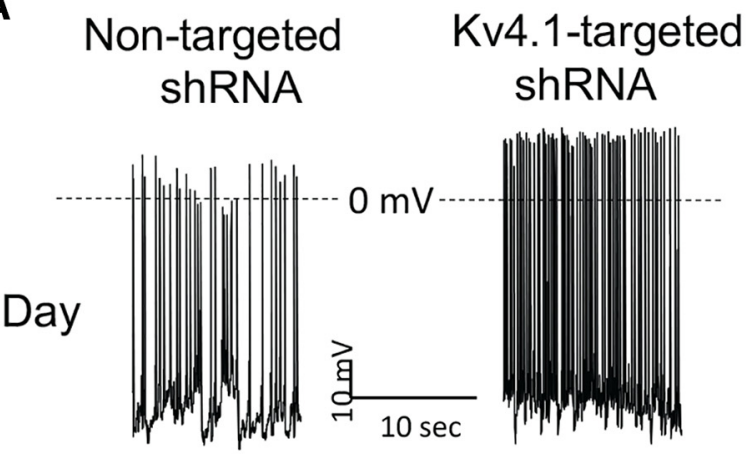

Night

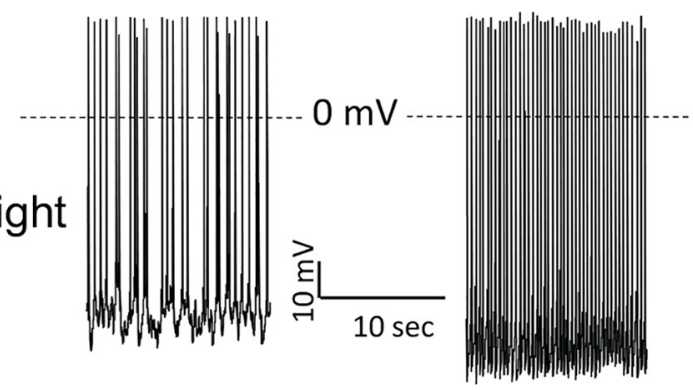

C
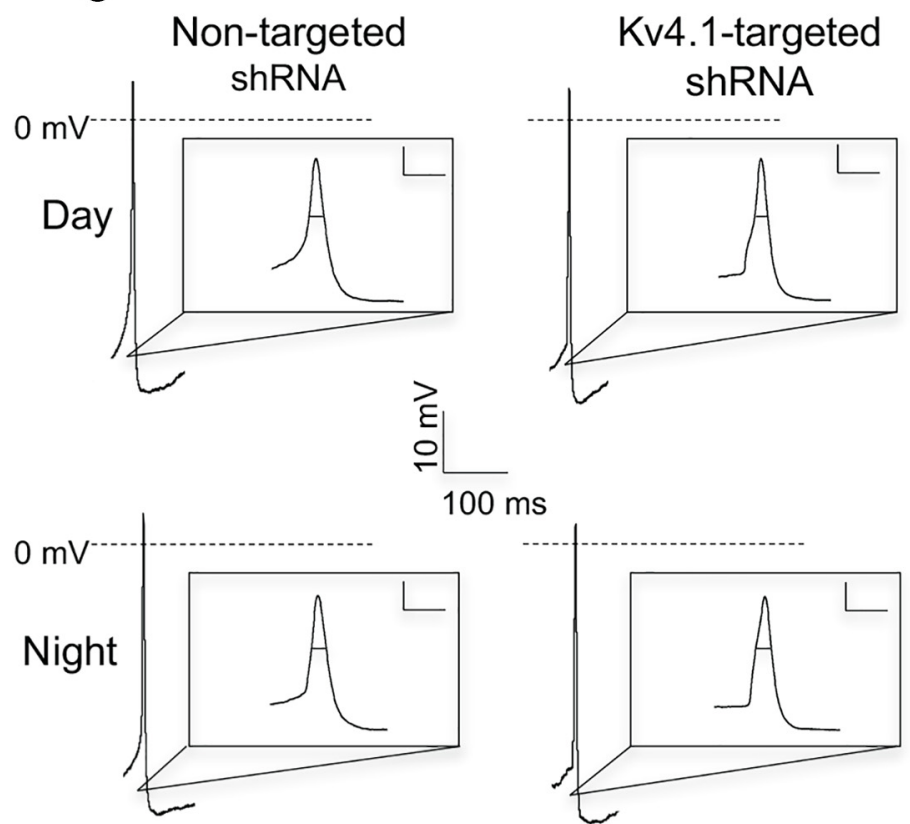

B

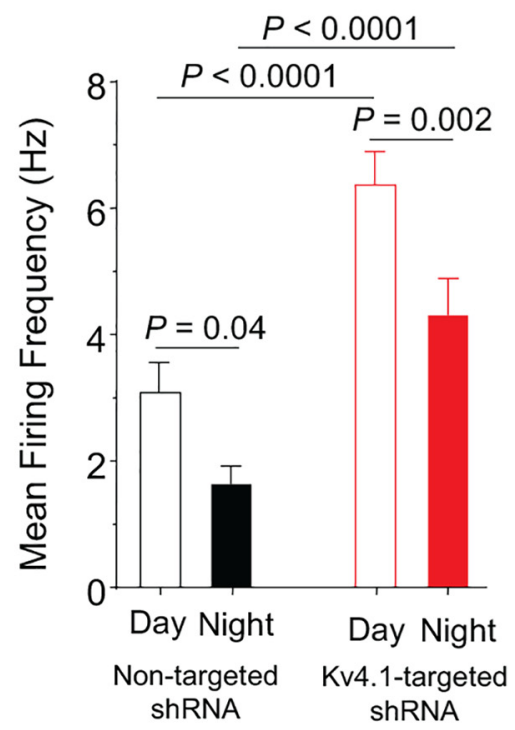

D

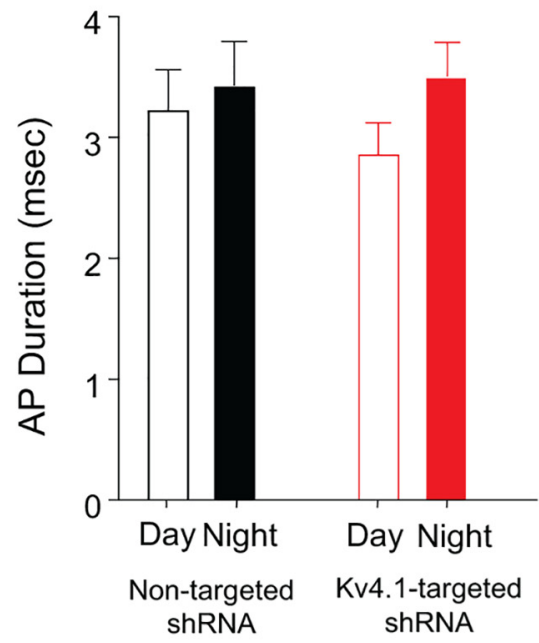

Figure 3. Acute knockdown of Kv4.1 increases spontaneous firing rates in SCN neurons during the day and at night. $\boldsymbol{A}$, Representative daytime (top) and nighttime (bottom) whole-cell current-clamp recordings obtained from nontargeted shRNAexpressing (left) and Kv4.1-targeted shRNA-expressing (right) SCN neurons are illustrated. B, Mean \pm SEM firing frequencies in both nontargeted shRNA-expressing $(n=17-27)$ and Kv4.1-targeted shRNA-expressing neurons $(n=24-26)$ are significantly higher during the day than at night. In addition, the mean \pm SEM daytime and nighttime firing frequencies in Kv4.1-targeted shRNAexpressing SCN neurons $(n=24-26)$ are significantly higher than in nontargeted shRNA-expressing $(n=17-27)$ SCN neurons; $p$ values (one-way ANOVA) are indicated. $\boldsymbol{C}$, Representative action potential waveforms recorded in nontargeted shRNA-expressing (left) and Kv4.1-targeted shRNA-expressing (right) SCN neurons during the day (top) and at night (bottom) are shown. The records are also illustrated on an expanded time scale in the insets (scale bar, $10 \mathrm{mV}$ and $10 \mathrm{~ms}$ ). $\boldsymbol{D}$, The mean $\pm \mathrm{SEM} \mathrm{APD}_{50}$ values determined in both nontargeted shRNA-expressing $(n=16-26)$ and Kv4.1-targeted shRNA-expressing neurons $(n=24-26)$ were not significantly $(p>0.05$, one-way ANOVA) different during the day or at night (Table 1). 

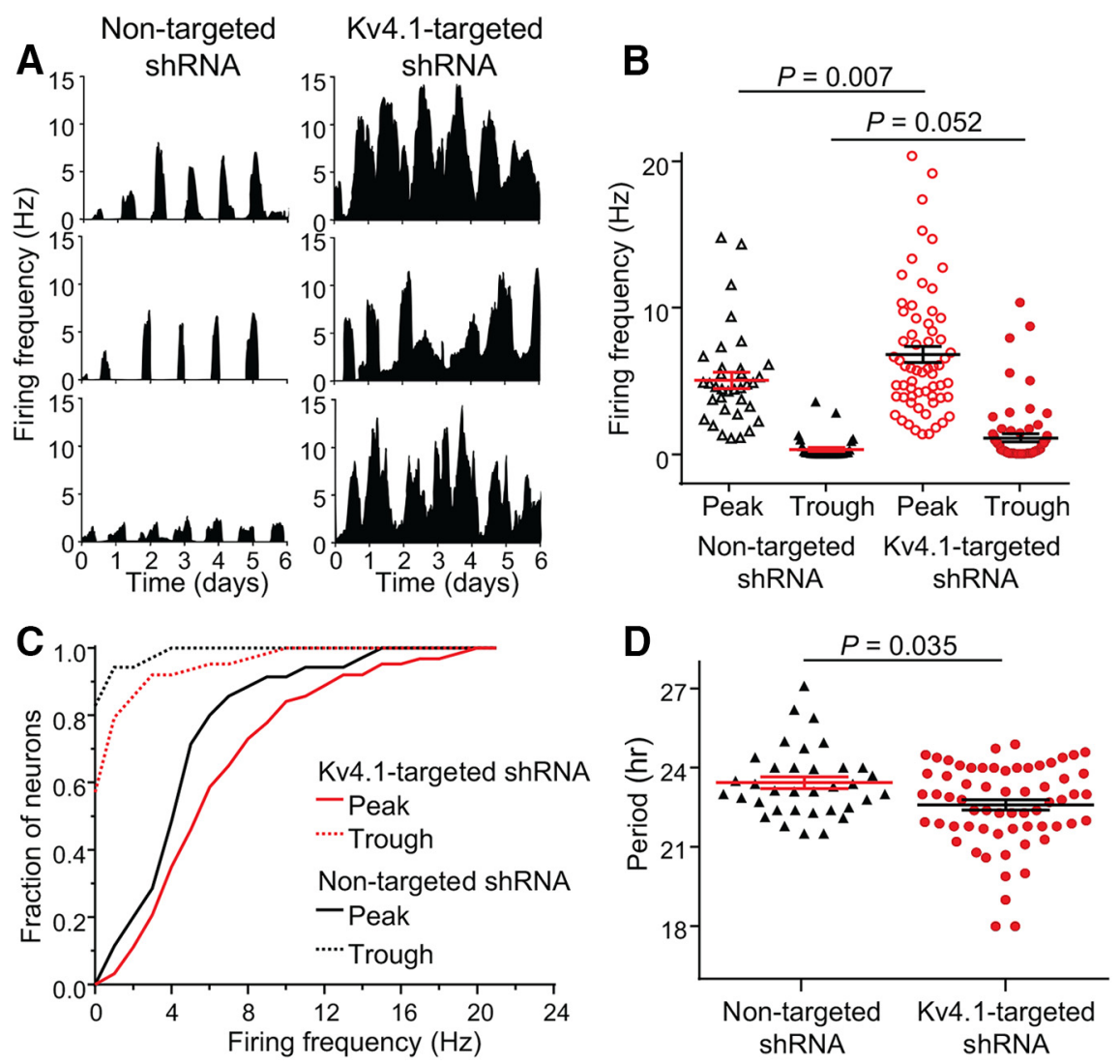

Figure 4. Acute knockdown of Kv4.1 alters the frequency and period of circadian firing in SCN neurons. Spontaneous firing was recorded continuously (over $6 \mathrm{~d}$ ) from SCN neurons in dispersed cultures. A, Representative recordings from three SCN neurons in cultures transduced with either the nontargeted shRNA-expressing (left) or the Kv4.1-targeted shRNA-expressing (right) AAV8 are shown. $\boldsymbol{B}$, The average peak and trough repetitive firing rates, measured in individual nontargeted shRNA-expressing (black open and filled triangles; $n=35$ ) and Kv4.1-targeted shRNA-expressing (red open and filled circles; $n=63$ ) SCN neurons are plotted; mean \pm SEM values are indicated. As is evident, mean \pm SEM peak firing rates were significantly higher in Kv4.1-targeted shRNA-expressing, compared with nontargeted shRNA-expressing, SCN neurons; $p$ values (one-way ANOVA) are indicated. $\boldsymbol{C}$, Cumulative distribution plots of peak and trough firing rates reveal rightward shifts (toward higher frequencies) in Kv4.1-targeted shRNA-expressing, compared with nontargeted shRNA-expressing, SCN neurons ( $p<0.05$, two-sample Kolmogorov-Smirnov test). $\boldsymbol{D}$, The circadian periods of firing measured in individual nontargeted shRNA-expressing $(n=35)$ and Kv4.1-targeted shRNAexpressing $(n=63)$ SCN neurons are plotted; mean \pm SEM values are indicated. The mean \pm SEM period was significantly $(p<$ 0.035; Mann-Whitney-Wilcoxon test) shorter in SCN neurons expressing the Kv4.1-targeted shRNA, compared with cells expressing the nontargeted shRNA.

were electrically silent during the trough (Fig. 4C)'. In contrast, the majority of Kv4.1 shRNA-expressing SCN neurons fired repetitively at $1 \mathrm{~Hz}$ or higher during the trough (Fig. 4C) ${ }^{i}$. The mean circadian period was also significantly $(p=0.035)$ shorter in SCN neurons transduced with the Kv4.1-targeted shRNA-expressing (22.7 \pm $0.2 \mathrm{~h}$ ), compared with nontargeted shRNA-expressing $(23.3 \pm 0.2$ h), AAV8 (Fig. 4D)

\section{Knockdown of Kv4.1 shortens the circadian period of clock gene expression}

To determine whether the loss of Kv4.1 also plays a role in setting the period of clock gene expression, we measured bioluminescence in Per2 ${ }^{\mathrm{Luc}} \mathrm{SCN}$ explants transduced with the Kv4.1-targeted shRNA- or the nontargeted shRNA-expressing AAV8. As illustrated in Figure $5 A$, all SCN explants examined exhibited high amplitude circadian rhythms for at least $5 \mathrm{~d}$. The mean period of Per2 ${ }^{\text {Luc }}$ expression in SCN explants expressing the Kv4.1- targeted shRNA $(23.7 \pm 0.1 \mathrm{~h})$ was significantly $(p<$ $0.004)$ shorter than in the SCN explants expressing the nontargeted shRNA $(24.6 \pm 0.1 \mathrm{~h}$; Fig. $5 B)$ '. The peak-totrough amplitudes of the oscillations, however, were not significantly $(p>0.05)$ different in Kv4.1-targeted shRNAexpressing (332144 \pm 140590 counts/10 min) and nontargeted shRNA-expressing (383865 \pm 72192 counts/10 min) SCN explants. The acute knockdown of Kv4.1, therefore, markedly affected the circadian period, but not the amplitude, of clock gene (Per2 ${ }^{\text {Luc }}$ ) expression in the SCN (see Discussion).

\section{Knockdown of Kv4.1 shortens the circadian period of wheel-running activity}

Representative recordings of wheel-running activity in mice following injection of the Kv4.1-targeted or the nontargeted shRNA-expressing AAV8 are illustrated in Figure $6 A$. In a standard 12:12 h LD cycle, mice injected with the Kv4.1-targeted shRNA- or the nontargeted shRNA- 

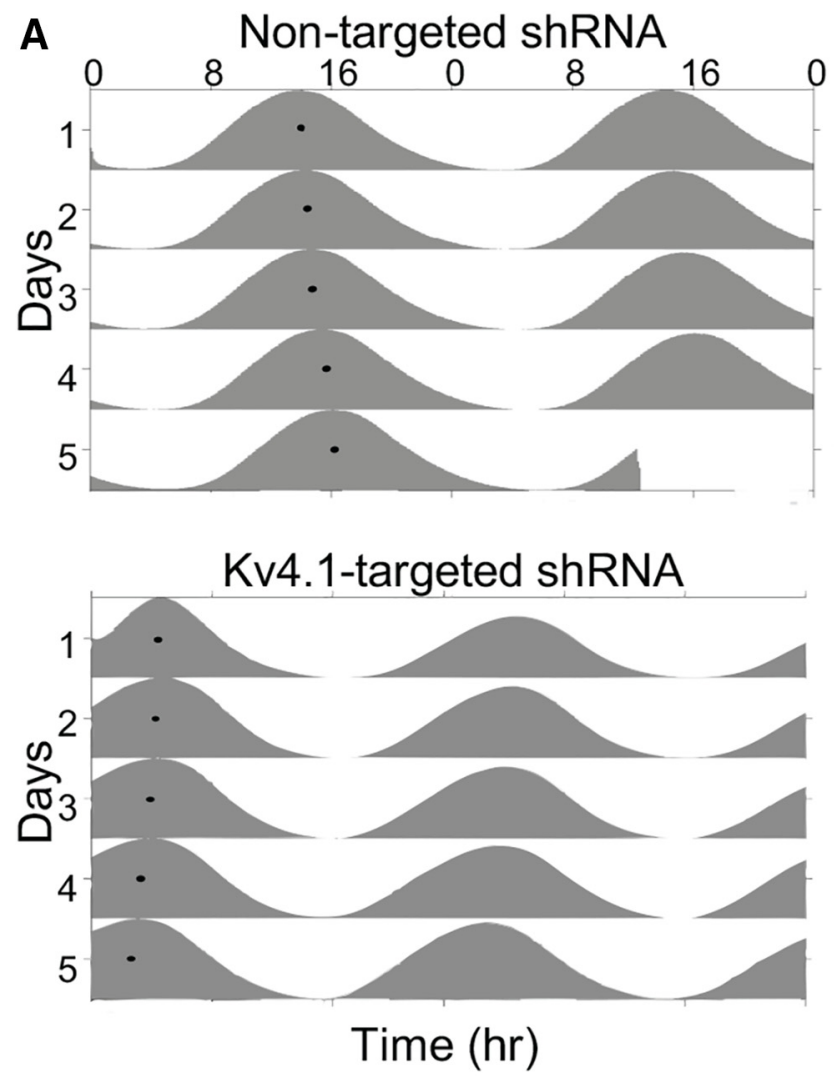

B

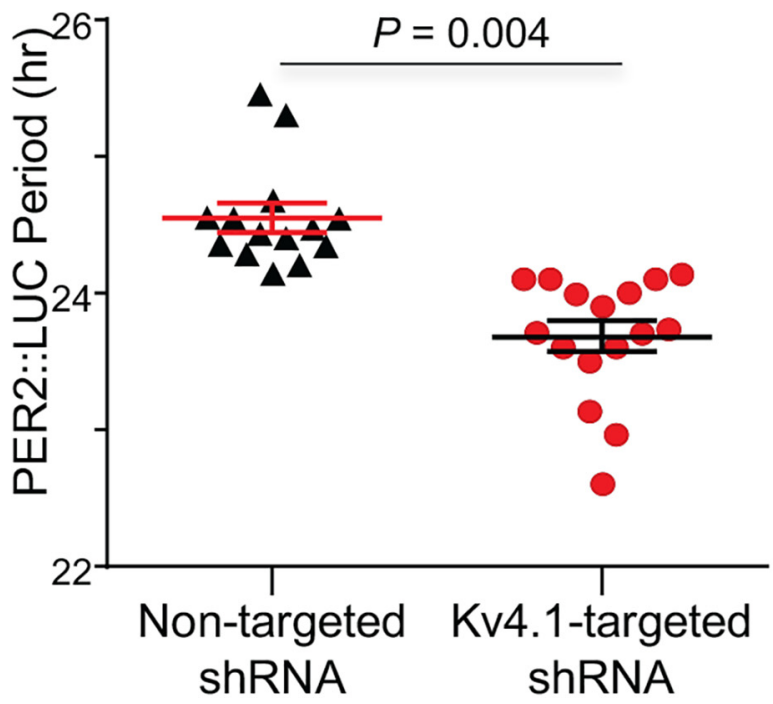

Figure 5. Acute knockdown of Kv4.1 shortens the circadian period of PER2 ${ }^{\mathrm{LUC}}$ expression in isolated SCN. $\boldsymbol{A}$, Representative PER2 ${ }^{\mathrm{LUC}}$ bioluminescence recordings, shown as doubleplotted actograms, were obtained from isolated SCN infected with the nontargeted shRNA-expressing (top) or the Kv4.1-targeted shRNA-expressing (bottom) AAV8. The black dots on the left sides of each of the actograms represent the acrophase (the peak) of each rhythm. $\boldsymbol{B}$, The mean \pm SEM circadian period was significantly ( $p<0.004$; Student's $t$ test) shorter in SCN transduced with the Kv4.1-targeted shRNA-expressing $(n=16)$, compared with the nontargeted shRNA-expressing ( $n=14)$, AAV8. expressing AAV8 entrained normally, showing no differences in the time of daily activity onset (Kv4.1-targeted shRNA: $18: 57 \pm 0.1 \mathrm{~h}$ and nontargeted shRNA: 18:29 \pm $0.3 \mathrm{~h})$. In DD, the circadian period of wheel-running was significantly $(p<0.005)$ shorter in mice injected with the Kv4.1-targeted shRNA-expressing AAV8 $(23.5 \pm 0.1 \mathrm{~h})$ than in mice receiving the nontargeted shRNA-expressing AAV8 $(23.8 \pm 0.1 \mathrm{~h} \text {; Fig. } 6 B)^{\mathrm{m}}$. In addition, $\sim 50 \%$ of the mice expressing the Kv4.1-targeted shRNA had shorter periods than any of the mice expressing the nontargeted shRNA (Fig. $6 C$ ) ${ }^{\mathrm{n}}$. Total activity during both the subjective day and night, however, was unaffected by the knockdown of Kv4.1 in the SCN (Kv4.1-targeted shRNA: $19800 \pm 1603$ counts/10 min during the active phase and $502 \pm 180$ counts/10 min during the inactive phase; nontargeted shRNA: $19750 \pm 1653$ counts/10 min during the active phase and $634 \pm 200$ counts/10 min during the inactive phase). Furthermore, the relative amount of time spent running-to-resting each day $(\alpha / \rho)$ was not significantly different in Kv4.1-targeted shRNA-expressing $(2.4 \pm 0.4 \mathrm{~h})$ and nontargeted shRNA-expressing $(2.1 \pm 0.2 \mathrm{~h})$ mice.

\section{Discussion}

The results presented here provided the first direct demonstration of a functional role for Kv4.1-encoded $\mathrm{I}_{\mathrm{A}}$ channels in the mammalian brain. Although Kcnd1 (Kv4.1) was the first member of the Kv4 subfamily cloned (Pak et al., 1991), it is expressed at much lower levels than the other members of this subfamily, Kcnd2 (Kv4.2) and Kcnd3 (Kv4.3) in most brain regions (Serodio et al., 1996) and most of the functional studies have focused on defining the properties and physiologic roles of $\mathrm{Kv} 4.2-$ and Kv4.3-encoded I $\mathrm{A}_{\mathrm{A}}$ channels (Kim et al., 2005; Chen et al., 2006; Andrasfalvy et al., 2008; Carrasquillo et al., 2012). In the striatum (Song et al., 1998) and amygdala (Dabrowska and Rainnie, 2010) and in dorsal root ganglion neurons (Phuket and Covarrubias, 2009), where Kcnd1 expression is high, roles for Kv4.1-encoded $I_{A}$ channels have been inferred, although the molecular and/or pharmacological approaches used targeted all members of the Kv4subfamily and were not selective for Kv4.1. In the experiments here, we used a Kv4.1-selective shRNA to show directly that Kv4.1 contributes to the generation of $\mathrm{I}_{\mathrm{A}}$ in adult mouse SCN neurons and, in addition, that Kv4.1encoded $\mathrm{I}_{A}$ channels function in the regulation of the active and passive membrane properties of SCN neurons as well as daily rhythms in repetitive firing, clock gene expression and locomotor behavior.

\section{Kv4.1 regulates circadian periodicity}

Acute in vivo knockdown of Kv4.1 expression in adult mouse SCN neurons significantly shortened the circadian period of electrical activity, clock gene expression, and locomotor behavior. These observations demonstrate that changes in membrane excitability feedback to the molecular clock, resulting in alterations in circadian rhythms and behavioral outputs. This conclusion is consistent with several previous studies using pharmacological, molecular genetic, and/or optogenetic approaches to manipulate the excitability of SCN neurons in vivo (Lundkvist et al., 2005; Granados-Fuentes et al., 2012; 

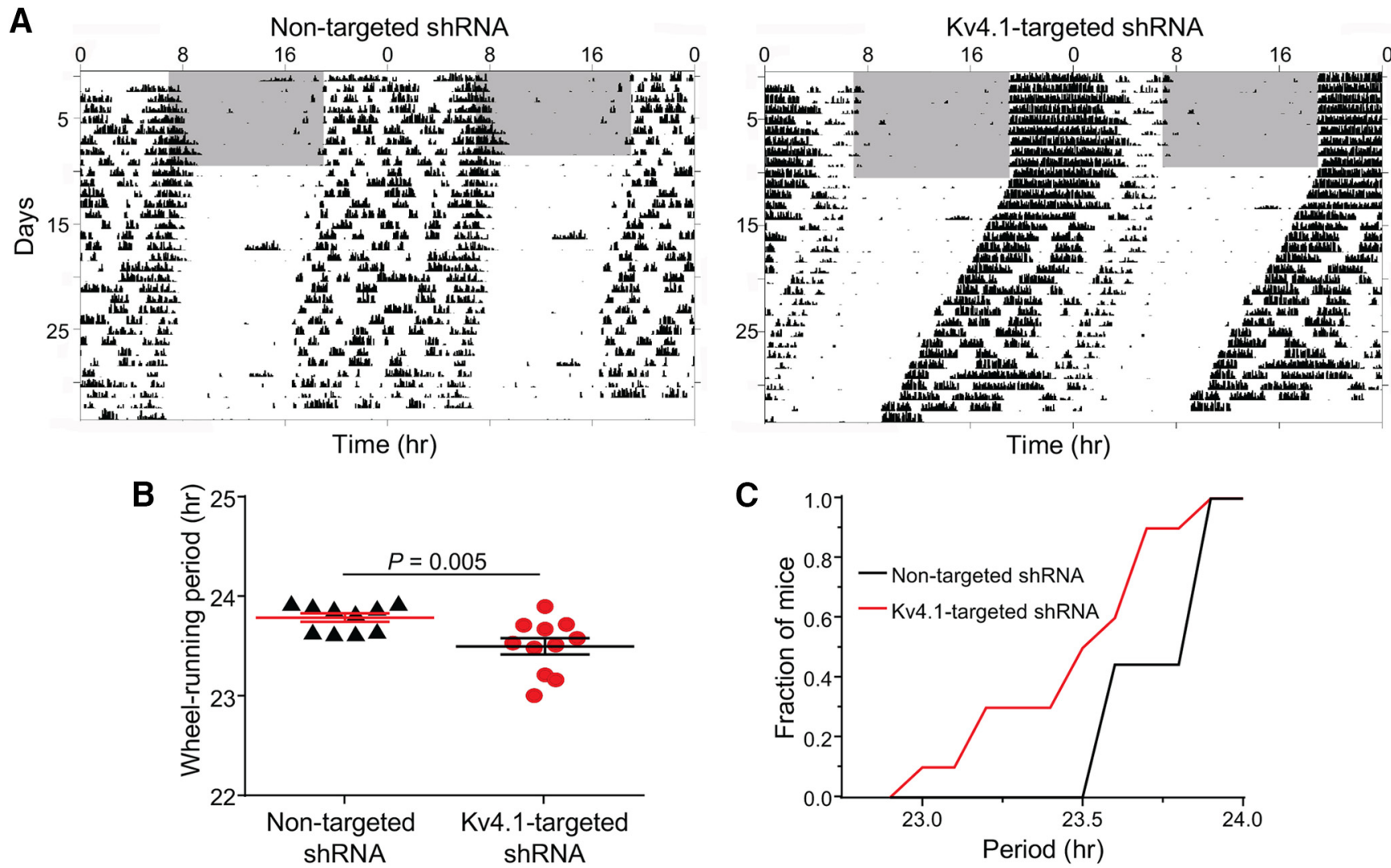

Figure 6. Acute knockdown of Kv4.1 shortens the circadian period of locomotor behavior. $\boldsymbol{A}$, Representative recordings of the wheel-running activity of mice that received bilateral SCN injections of either the nontargeted shRNA-expressing (left) or the Kv4.1-targeted shRNA-expressing (right) AAV8. Over 50 consecutive days, the activity of each mouse was recorded in different light-dark (indicated by the gray and white backgrounds, respectively) conditions. Each line shows wheel revolutions per minute over a 48 -h period. $\boldsymbol{B}$, The mean \pm SEM circadian period of locomotor activity in DD was significantly $(p<0.001$; Student's $t$ test) shorter in mice expressing the Kv4.1-targeted shRNA $(n=11)$, compared with mice expressing the nontargeted shRNA ( $n=10)$. $\boldsymbol{C}$, Cumulative distribution plots of the intrinsic periods of locomotive activity also revealed that $\sim 50 \%$ of mice transduced with the Kv4.1-targeted shRNA-expressing AAV8 had significantly ( $p<0.0001$, two-sample Kolmogorov-Smirnov test) shorter periods in DD than mice infected with the nontargeted shRNA-expressing AAV8.

Granados-Fuentes et al., 2015; Jones et al., 2015). Indeed, it has been shown, using targeted deletion strategies that Kv1.4- and Kv4.2-, but not Kv4.3-, encoded I channels also regulate SCN excitability and circadian rhythms in behavior and clock gene expression (Granados-Fuentes et al., 2012; Granados-Fuentes et al., 2015). Daily changes in the excitability of SCN neurons, mediated at least in part by $\mathrm{I}_{\mathrm{A}}$ channels, therefore, lie both on the input to, and output from, the molecular clock.

\section{Kv4.1 regulates intrinsic firing properties in SCN neurons}

Daily rhythms in the intrinsic membrane properties and the spontaneous firing rates of mammalian SCN neurons have been studied extensively (Green and Gillette, 1982; de Jeu et al., 1998; Meredith et al., 2006; Colwell, 2011). Although there are some differences in absolute values reported, on average, daytime repetitive firing rates are $\sim 5 \mathrm{~Hz}$, whereas, at night, repetitive firing rates are $\sim 1 \mathrm{~Hz}$ and a number of $\mathrm{K}_{\mathrm{v}}$ (Kudo et al., 2011) and voltage-gated $\mathrm{Na}^{+}$(Jackson et al., 2004; Paul et al., 2016), as well as $\mathrm{Ca}^{2+}$-dependent $\mathrm{K}^{+}$(Meredith et al., 2006), channels have been shown to contribute to the regulation of repet- itive firing rates in SCN neurons. In addition, however, the $\mathrm{R}_{\text {in }}$ of $\mathrm{SCN}$ neurons are higher during the day than at night, findings interpreted as suggesting that the observed day-night differences in repetitive firing rates are mediated, at least in part, by diurnal changes in subthreshold $\mathrm{K}^{+}$conductance(s) (Kuhlman and McMahon, 2004; Flourakis et al., 2015). Unlike many other $\mathrm{K}_{\mathrm{v}}$ currents, A-type channels, in addition to regulating repetitive firing rates, function in the subthreshold range of membrane potentials in some neuronal cell-types (Kim et al., 2005; Carrasquillo et al., 2012). As illustrated in Figure 2G, a clear $I_{A}$ window current is observed over the voltage range ( -35 to $-55 \mathrm{mV}$ ) of $\mathrm{V}_{\mathrm{r}}$ typically observed of SCN neurons (Table 1), indicating that some $I_{A}$ channels are open at these potentials. The increases in $R_{\text {in }}$ and repetitive firing rates observed here in the targeted shRNA expressing cells reveals a role for Kv4.1, either alone or with other Kv4 subfamily members, in the generation of the critical $I_{A}$ channels.

Expression of the Kv4.1-targeted shRNA significantly decreased ISIs and increased repetitive firing rates in SCN neurons during the day and at night, suggesting that $\mathrm{Kv} 4.1$-encoded $\mathrm{I}_{\mathrm{A}}$ channels function by acting as a 
"brake" to control repetitive firing rates at all times throughout the day. In recordings from dispersed SCN neurons, we also observed a significant increase in repetitive firing rates during the peak (subjective day) and the trough (subjective night) of electrical activity over multiple days.

The results presented here also revealed that the acute knockdown of Kv4.1 had differential effects on the daytime and nighttime $R_{\text {in }}$ and repetitive firing rates in SCN neurons. During the day, the mean repetitive firing rate of SCN neurons expressing the Kv4.1-targeted shRNA was approximately twice the rate measured in control SCN neurons expressing the nontargeted shRNA. At night, however, the mean repetitive firing rate of Kv4.1-targeted shRNA-expressing SCN neurons was three-fold higher than in control, nontargeted shRNA-expressing cells. The effects of Kv4.1 knockdown on the $R_{\text {in }}$ of SCN neurons and on the amplitudes of $\mathrm{I}_{\mathrm{A}}$ were also greater at night than during the day. These observations suggest that the expression of Kv4.1 may be under circadian control. Data deposited in the CircaDB circadian expression profiles database (http://circadb.hogeneschlab.org), however, indicate that Kcnd1 transcript expression does not vary with time of day. It has also been reported that the expression of the Kv4.1 protein is similar at night and during the day (Itri et al., 2010). Unfortunately, owing to the lack of availability of a Kv4.1-targeted deletion (Kv4.1 ${ }^{-/-}$) mouse line, the antibody used to probe Kv4.1 protein expression in this study has not been validated to date. Additional studies focused on examining Kv4.1 protein expression will need to be done when a Kv4.1 ${ }^{-1-}$ mouse line and validated anti-Kv4.1 antibodies become availiable. It is certainly also possible that day-night differences in the functional expression of $\mathrm{Kv} 4$.1-encoded $\mathrm{I}_{\mathrm{A}}$ could be produced by rhythmic changes in posttranslational modifications of the Kv4.1 $\alpha$-subunit or of accessory subunits, as recently suggested for circadian regulation of the persistent $\mathrm{Na}^{+}$current in SCN neurons (Paul et al., 2016). The availability of validated anti-Kv4.1 antibodies will also make it possible to test these hypotheses directly.

\section{References}

Alvado L, Allen CN (2008) Tetraethylammomum (TEA) increases the inactivation time constant of the transient $\mathrm{K}+$ current in suprachiasmatic nucleus neurons. Brain Res 1221:24-29.

Andrasfalvy BK, Makara JK, Johnston D, Magee JC (2008) Altered synaptic and non-synaptic properties of CA1 pyramidal neurons in Kv4.2 knockout mice. J Physiol 586:3881-3892. CrossRef

Aton SJ, Block GD, Tei H, Yamazaki S, Herzog ED (2004) Plasticity of circadian behavior and the suprachiasmatic nucleus following exposure to non-24-hour light cycles. J Biol Rhythms 19:198-207. CrossRef

Aton SJ, Colwell CS, Harmar AJ, Waschek J, Herzog ED (2005) Vasoactive intestinal polypeptide mediates circadian rhythmicity and synchrony in mammalian clock neurons. Nat Neurosci 8:476483. CrossRef Medline

Baldwin TJ, Tsaur ML, Lopez GA, Jan YN, Jan LY (1991) Characterization of a mammalian cDNA for an inactivating voltage-sensitive K+ channel. Neuron 7:471-483. Medline

Bouskila Y, Dudek FE (1995) A rapidly activating type of outward rectifier $\mathrm{K}+$ current and $\mathrm{A}$-current in rat suprachiasmatic nucleus neurons. J Physiol 488:339-350. CrossRef
Carrasquillo Y, Burkhalter A, Nerbonne JM (2012) A-type K+ channels encoded by Kv4.2, Kv4.3 and Kv1.4 differentially regulate intrinsic excitability of cortical pyramidal neurons. J Physiol 590: 3877-3890. CrossRef

Chen XX, Yuan LL, Zhao CP, Birnbaum SG, Frick A, Jung WE, Schwarz TL, Sweatt JD, Johnston D (2006) Deletion of Kv4.2 gene eliminates dendritic A-type $\mathrm{K}+$ current and enhances induction of long-term potentiation in hippocampal CA1 pyramidal neurons. J Neurosci 26:12143-12151. CrossRef

Colwell CS (2011) Linking neural activity and molecular oscillations in the SCN. Nat Rev Neurosci 12:553-569. CrossRef Medline

Dabrowska J, Rainnie DG (2010) Expression and distribution of Kv4 potassium channel subunits and potassium channel interacting proteins in subpopulations of interneurons in the basolateral amygdala. Neuroscience 171:721-733. CrossRef Medline

de Jeu M, Hermes M, Pennartz C (1998) Circadian modulation of membrane properties in slices of rat suprachiasmatic nucleus. Neuroreport 9:3725-3729. Medline

Flourakis M, Kula-Eversole E, Hutchison AL, Han TH, Aranda K, Moose DL, White KP, Dinner AR, Lear BC, Ren DJ, Diekman CO, Raman IM, Allada R (2015) A conserved bicycle model for circadian clock control of membrane excitability. Cell 162:836-848. CrossRef

Granados-Fuentes D, Norris AJ, Carrasquillo Y, Nerbonne JM, Herzog ED (2012) I(A) channels encoded by Kv1.4 and Kv4.2 regulate neuronal firing in the suprachiasmatic nucleus and circadian rhythms in locomotor activity. J Neurosci 32:10045-10052. CrossRef Medline

Granados-Fuentes D, Hermanstyne TO, Carrasquillo Y, Nerbonne JM, Herzog ED (2015) I-A channels encoded by Kv1.4 and Kv4.2 regulate circadian period of PER2 expression in the suprachiasmatic nucleus. J Biol Rhythms 30:396-407. CrossRef Medline

Green DJ, Gillette R (1982) Circadian rhythm of firing rate recorded from single cells in the rat suprachiasmatic brain slice. Brain Res 245:198-200. Medline

Gutman GA, Chandy KG, Grissmer S, Lazdunski M, Mckinnon D, Pardo LA, Robertson GA, Rudy B, Sanguinetti MC, Stuhmer W, Wang XL (2005) International Union of Pharmacology. LIII. nomenclature and molecular relationships of voltage-gated potassium channels. Pharmacol Rev 57:473-508. CrossRef

Hattar S, Kumar M, Park A, Tong P, Tung J, Yau KW, Berson DM (2006) Central projections of melanopsin-expressing retinal ganglion cells in the mouse. J Comp Neur 497:326-349. CrossRef Medline

Hermanstyne TO, Simms CL, Carrasquillo Y, Herzog ED, Nerbonne JM (2016) Distinct firing properties of vasoactive intestinal peptide-expressing neurons in the suprachiasmatic nucleus. J Biol Rhythms 31:57-67. CrossRef Medline

Herzog ED, Takahashi JS, Block GD (1998) Clock controls circadian period in isolated suprachiasmatic nucleus neurons. Nat Neurosci 1:708-713. CrossRef

Hoffman DA, Magee JC, Colbert CM, Johnston D (1997) K+ channel regulation of signal propagation in dendrites of hippocampal pyramidal neurons. Nature 387:869-875. CrossRef Medline

Itri JN, Vosko AM, Schroeder A, Dragich JM, Michel S, Colwell CS (2010) Circadian regulation of A-type potassium currents in the suprachiasmatic nucleus. J Neurophysiol 103:632-640. CrossRef Medline

Jackson AC, Yao GL, Bean BP (2004) Mechanism of spontaneous firing in dorsomedial suprachiasmatic nucleus neurons. J Neurosci 24:7985-7998. CrossRef Medline

Jerng HH, Pfaffinger PJ, Covarrubias M (2004) Molecular physiology and modulation of somatodendritic A-type potassium channels. Mol Cell Neurosci 27:343-369. CrossRef Medline

Jones JR, Tackenberg MC, McMahon DG (2015) Manipulating circadian clock neuron firing rate resets molecular circadian rhythms and behavior. Nat Neurosci 18:373-375. CrossRef Medline

Kalsbeek A, Buijs RM (2002) Output pathways of the mammalian suprachiasmatic nucleus: coding circadian time by transmitter 
selection and specific targeting. Cell Tissue Res 309:109-118. CrossRef Medline

Kim J, Wei DS, Hoffman DA (2005) Kv4 potassium channel subunits control action potential repolarization and frequency-dependent broadening in rat hippocampal CA1 pyramidal neurones. J Physiol 569:41-57. CrossRef

Kudo T, Loh DH, Kuljis D, Constance C, Colwell CS (2011) Fast delayed rectifier potassium current: critical for input and output of the circadian system. J Neurosci 31:2746-2755. CrossRef Medline

Kuhlman SJ, McMahon DG (2004) Rhythmic regulation of membrane potential and potassium current persists in SCN neurons in the absence of environmental input. Eur J Neurosci 20:1113-1117. CrossRef Medline

Lundkvist GB, Kwak Y, Davis EK, Tei H, Block GD (2005) A calcium flux is required for circadian rhythm generation in mammalian pacemaker neurons. J Neurosci 25:7682-7686. CrossRef Medline

Maier B, Wendt S, Vanselow JT, Wallach T, Reischl S, Oehmke S, Schlosser A, Kramer A (2009) A large-scale functional RNAi screen reveals a role for CK2 in the mammalian circadian clock. Genes Dev 23:708-718. CrossRef Medline

Meredith AL, Wiler SW, Miller BH, Takahashi JS, Fodor AA, Ruby NF, Aldrich RW (2006) BK calcium-activated potassium channels regulate circadian behavioral rhythms and pacemaker output. Nat Neurosci 9:1041-1049. CrossRef Medline

Norris AJ, Nerbonne JM (2010) Molecular dissection of I-A in cortical pyramidal neurons reveals three distinct components encoded by Kv4.2, Kv4.3, and Kv1.4 alpha-subunits. J Neurosci 30:50925101. CrossRef Medline

Norris AJ, Foeger NC, Nerbonne JM (2010) Interdependent roles for accessory KChIP2, KChIP3, and KChIP4 subunits in the generation of Kv4-encoded IA channels in cortical pyramidal neurons. J Neurosci 30:13644-13655. CrossRef Medline

Pak MD, Baker K, Covarrubias M, Butler A, Ratcliffe A, Salkoff L (1991) Mshal, a subfamily of A-type $K+$ channel cloned from mammalian brain. Proc Natl Acad Sci USA 88:4386-4390. Medline

Paul JR, DeWoskin D, McMeekin LJ, Cowell RM, Forger DB, Gamble KL (2016) Regulation of persistent sodium currents by glycogen synthase kinase 3 encodes daily rhythms of neuronal excitability. Nat Commun 7:13470. CrossRef
Pennartz CM, de Jeu MT, Bos NP, Schaap J, Geurtsen AM (2002) Diurnal modulation of pacemaker potentials and calcium current in the mammalian circadian clock. Nature 416:286-290. CrossRef Medline

Phuket TR, Covarrubias M (2009) Kv4 channels underlie the subthreshold-operating A-type K-current in nociceptive dorsal root ganglion neurons. Front Mol Neurosci 2:1-14.

Pongs O (1999) Voltage-gated potassium channels: from hyperexcitability to excitement. FEBS Lett 452:31-35. Medline

Rogawski MA (1985) The A-current - how ubiquitous a feature of excitable cells is it. Trends Neurosci 8:214-219. CrossRef

Rudy B (1988) Diversity and ubiquity of K-channels. Neuroscience 25:729-749. Medline

Schaap J, Bos NP, de Jeu MT, Geurtsen AM, Meijer JH, Pennartz CM (1999) Neurons of the rat suprachiasmatic nucleus show a circadian rhythm in membrane properties that is lost during prolonged whole-cell recording. Brain Res 815:154-166. Medline

Serodio P, Rudy B (1998) Differential expression of Kv4 K+ channel subunits mediating subthreshold transient $\mathrm{K}+$ (A-type) currents in rat brain. J Neurophysiol 79:1081-1091.

Serodio P, Vega-Saenz de Miera E, Rudy B (1996) Cloning of a novel component of A-type $\mathrm{K}+$ channels operating at subthreshold potentials with unique expression in heart and brain. $J$ Neurophysiol 75:2174-2179.

Sokolove PG, Bushell WN (1978) The chi square periodogram: its utility for analysis of circadian-rhythms. J Theor Biol 72:131-160. Medline

Song WJ, Tkatch T, Baranauskas G, Ichinohe N, Kitai ST, Surmeier DJ (1998) Somatodendritic depolarization-activated potassium currents in rat neostriatal cholinergic interneurons are predominantly of the A type and attributable to coexpression of Kv4.2 and Kv4.1 subunits. J Neurosci 18:3124-3137. Medline

Welsh DK, Logothetis DE, Meister M, Reppert SM (1995) Individual neurons dissociated from rat suprachiasmatic nucleus express independently phased circadian firing rhythms. Neuron 14:697706. Medline

Yoo SH, Yamazaki S, Lowrey PL, Shimomura K, Ko CH, Buhr ED, Siepka SM, Hong HK, Oh WJ, Yoo OJ, Menaker M, Takahashi JS (2004) Period2::luciferase real-time reporting of circadian dynamics reveals persistent circadian oscillations in mouse peripheral tissues. Proc Natl Acad Sci USA 12:1-8. 